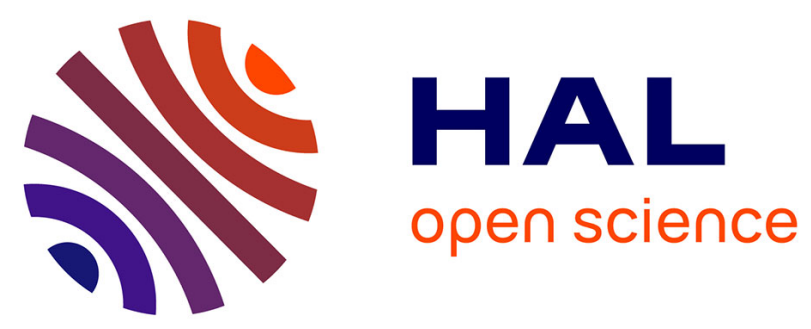

\title{
Atmospheric Hydrogen Peroxide (H 2 O 2 ) at the Foot and Summit of Mt. Tai: Variations, Sources and Sinks, and Implications for Ozone Formation Chemistry
}

Can Ye, Chaoyang Xue, Chenglong Zhang, Zhuobiao Ma, Pengfei Liu, Yuanyuan Zhang, Chengtang Liu, Xiaoxi Zhao, Wenjin Zhang, Xiaowei He, et al.

\section{To cite this version:}

Can Ye, Chaoyang Xue, Chenglong Zhang, Zhuobiao Ma, Pengfei Liu, et al.. Atmospheric Hydrogen Peroxide (H 2 O 2 ) at the Foot and Summit of Mt. Tai: Variations, Sources and Sinks, and Implications for Ozone Formation Chemistry. Journal of Geophysical Research: Atmospheres, 2021, 126 (15), 10.1029/2020JD033975 . insu-03319270

\section{HAL Id: insu-03319270 \\ https://hal-insu.archives-ouvertes.fr/insu-03319270}

Submitted on 12 Aug 2021

HAL is a multi-disciplinary open access archive for the deposit and dissemination of scientific research documents, whether they are published or not. The documents may come from teaching and research institutions in France or abroad, or from public or private research centers.
L'archive ouverte pluridisciplinaire HAL, est destinée au dépôt et à la diffusion de documents scientifiques de niveau recherche, publiés ou non, émanant des établissements d'enseignement et de recherche français ou étrangers, des laboratoires publics ou privés.

$$
\text { Copyright }
$$




\section{JGR Atmospheres}

\section{RESEARCH ARTICLE \\ 10.1029/2020JD033975 \\ Key Points: \\ Atmospheric Hydrogen Peroxide $\left(\mathrm{H}_{2} \mathrm{O}_{2}\right)$ at the Foot and Summit of Mt. Tai: Variations, Sources and Sinks, and Implications for Ozone Formation Chemistry}

- Gas-phase hydrogen peroxide $\left(\mathrm{H}_{2} \mathrm{O}_{2}\right)$ at the summit of Mt. Tai evidently increased from 2007 to 2018, which might be ascribed to volatile organic compounds (VOCs) increase and $\mathrm{SO}_{2}$ decline

- Observed $\mathrm{H}_{2} \mathrm{O}_{2}$ at the foot of Mt. Tai could be well reproduced by a box model with $\mathrm{H}_{2} \mathrm{O}_{2}$ dry deposition velocity of $3 \mathrm{~cm} \mathrm{~s}^{-1}$ included

- $\mathrm{O}_{3}$ formation in Tai'an city was mainly VOC-sensitive in the early morning and shifted to $\mathrm{NO}_{\mathrm{x}}$-sensitive thereafter

Supporting Information:

Supporting Information may be found in the online version of this article.

Correspondence to:

Y. $\mathrm{Mu}$,

yjmu@rcees.ac.cn

Citation:

Ye, C., Xue, C., Zhang, C., Ma, Z., Liu, P., Zhang, Y., et al. (2021). Atmospheric hydrogen peroxide $\left(\mathrm{H}_{2} \mathrm{O}_{2}\right)$ at the foot and summit of Mt. Tai: Variations, sources and sinks, and implications for ozone formation chemistry. Journal of Geophysical Research: Atmospheres, 126, e2020JD033975. https://doi. org/10.1029/2020JD033975

Received 27 SEP 2020 Accepted 16 JUL 2021

\author{
Can Ye ${ }^{1,2,3}\left(\mathbb{D}\right.$, Chaoyang Xue ${ }^{1,2,4}$, Chenglong Zhang ${ }^{1,2,5}$, Zhuobiao Ma ${ }^{1,2}$, Pengfei Liu ${ }^{1,2,5}$, \\ Yuanyuan Zhang ${ }^{1,2,5}$, Chengtang $\mathrm{Liu}^{1,2,5}$, Xiaoxi Zhao ${ }^{1,2}$, Wenjin $\mathrm{Zhang}^{1,2}$, Xiaowei $\mathrm{He}^{1,2}$, \\ Yifei Song ${ }^{1,2}$, Junfeng Liu ${ }^{1,2,5}$ (D), Weihao Wang ${ }^{6}$, Benhui Sui ${ }^{7}$, Ran Cui ${ }^{7}$, Xue Yang ${ }^{7}$, \\ Rubo Mei ${ }^{7}$, Jianmin Chen $^{8} \mathbb{C}^{-}$, and Yujing $\mathrm{Mu}^{1,2,5}$ (i)
}

${ }^{1}$ Research Centre for Eco-Environmental Sciences, Chinese Academy of Sciences, Beijing, China, ${ }^{2}$ University of Chinese Academy of Sciences, Beijing, China, ${ }^{3}$ Now at State Key Joint Laboratory of Environmental Simulation and Pollution Control, College of Environmental Sciences and Engineering, Peking University, Beijing, China, ${ }^{4}$ Laboratoire de Physique et Chimie de l'Environnement et de l'Espace (LPC2E), CNRS, CNES, Université Orléans, Orléans, France, ${ }^{5}$ Centre for Excellence in Regional Atmospheric Environment, Institute of Urban Environment, Chinese Academy of Sciences, Xiamen, China, ${ }^{6}$ Department of Civil and Environmental Engineering, The Hong Kong Polytechnic University, Hong Kong, China, ${ }^{7}$ Tai'an Municipal Ecological Environmental Bureau, Shandong Tai'an Ecological Environmental Monitoring Center, Tai'an, China, ${ }^{8}$ Shanghai Key Laboratory Atmospheric Particle Pollution and Prevention (LAP3), Department of Environmental Science and Engineering, Institute of Atmospheric Sciences, Fudan University, Shanghai, China

\section{Introduction}

Atmospheric hydrogen peroxide $\left(\mathrm{H}_{2} \mathrm{O}_{2}\right)$ is mainly produced by recombination of two hydroperoxy radicals $\left(\mathrm{HO}_{2}\right)$ which involve the photochemical reactions of atmospheric VOCs and carbon monoxide (CO):

$$
\begin{gathered}
\mathrm{VOCs}+\mathrm{OH} \stackrel{\mathrm{O}_{2}}{\rightarrow} \mathrm{RO}_{2}+\mathrm{H}_{2} \mathrm{O} \\
\mathrm{RO}_{2}+\mathrm{NO} \stackrel{\mathrm{O}_{2}}{\rightarrow} \mathrm{OVOC}+\mathrm{HO}_{2}+\mathrm{NO}_{2} \\
\mathrm{CO}+\mathrm{OH} \stackrel{\mathrm{O}_{2}}{\rightarrow} \mathrm{CO}_{2}+\mathrm{HO}_{2}
\end{gathered}
$$

C) 2021. American Geophysical Union. All Rights Reserved. 


$$
\mathrm{HO}_{2}+\mathrm{HO}_{2} \rightarrow \mathrm{H}_{2} \mathrm{O}_{2}+\mathrm{O}_{2}
$$

$\mathrm{H}_{2} \mathrm{O}_{2}$ formation through $\mathrm{R} 4$ is easily suppressed by the presence of nitric oxide (NO) because the reaction rate constant $\left(8.8 \times 10^{-12} \mathrm{~cm}^{3}\right.$ molecule $\left.\mathrm{s}^{-1} \mathrm{~s}^{-1}\right)$ of $\mathrm{R} 5$ is nearly five times greater than that $\left(1.5 \times 10^{-12} \mathrm{~cm}^{3} \mathrm{~mole}\right.$ cule $^{-1} \mathrm{~s}^{-1}$ ) of R4 at $298 \mathrm{~K}$ (Sander et al., 2003).

$$
\mathrm{HO}_{2}+\mathrm{NO} \rightarrow \mathrm{OH}+\mathrm{NO}_{2}
$$

Theoretically, $\mathrm{H}_{2} \mathrm{O}_{2}$ formation through $\mathrm{R} 4$ will be negligible when NO levels exceed 1 ppbv, which is also supported by most field observations (Hua et al., 2008; Nunnermacker et al., 2008; Walker et al., 2006; Watanabe et al., 2016). Besides $\mathrm{H}_{2} \mathrm{O}_{2}$ formation through R4, ozonolysis of unsaturated VOCs has been identified as another source of $\mathrm{H}_{2} \mathrm{O}_{2}$, which is usually considered to be the dominant source of $\mathrm{H}_{2} \mathrm{O}_{2}$ in nighttime (Becker et al., 1990, 1993). Furthermore, the photochemical reactions in liquid-phase, such as cloud, fog, and atmospheric particles, can also produce $\mathrm{H}_{2} \mathrm{O}_{2}$ (Anastasio et al., 1994; Faust et al., 1993; Herrmann et al., 2015; Zuo \& Hoigné, 1993). The atmospheric hydroxyl radicals $(\mathrm{OH})$ and $\mathrm{HO}_{2}$ can be recycled through R1-R3 and R5, whereas $\mathrm{H}_{2} \mathrm{O}_{2}$ formation through R4 terminates the circle of $\mathrm{HO}_{\mathrm{x}}$ radicals $\left(\mathrm{OH}\right.$ and $\left.\mathrm{HO}_{2}\right)$ because reproduction of $\mathrm{OH}$ radicals via $\mathrm{H}_{2} \mathrm{O}_{2}$ photolysis (R6) in the troposphere is very slow.

$$
\mathrm{H}_{2} \mathrm{O}_{2}+h v(\lambda \leq 360 \mathrm{~nm}) \rightarrow 2 \mathrm{OH}
$$

$\mathrm{H}_{2} \mathrm{O}_{2}$ formation through R4 usually acts as the dominant sink for $\mathrm{HO}_{\mathrm{x}}$ radicals under the condition with low $\mathrm{NO}$ levels or high VOCs $/ \mathrm{NO}_{\mathrm{x}}\left(\mathrm{NO}\right.$ and $\mathrm{NO}_{2}$ ) ratios. Under the condition with relatively high $\mathrm{NO}$ levels or low VOCs $/ \mathrm{NO}_{\mathrm{x}}$ ratios, however, the termination of $\mathrm{HO}_{\mathrm{x}}$ radicals is usually dominated by the reaction of $\mathrm{NO}_{2}$ with $\mathrm{OH}$ (Tan et al., 2018):

$$
\mathrm{NO}_{2}+\mathrm{OH} \rightarrow \mathrm{HNO}_{3}
$$

When $\mathrm{H}_{2} \mathrm{O}_{2}$ formation through $\mathrm{R} 4$ acts as the dominant sink for $\mathrm{HO}_{\mathrm{x}}$ radicals, more $\mathrm{NO}_{\mathrm{x}}$ will accelerate the conversion rate of $\mathrm{NO}$ to $\mathrm{NO}_{2}$ through $\mathrm{R} 2$ and $\mathrm{R} 5$ leading to more $\mathrm{O}_{3}$ formation via photolysis of $\mathrm{NO}_{2}$, whereas additional VOCs will lead negligible influence on $\mathrm{O}_{3}$ because of the limited $\mathrm{NO}_{\mathrm{x}}$ levels. When $\mathrm{HNO}_{3}$ formation through $\mathrm{R} 7$ acts as the dominant sink for atmospheric $\mathrm{HO}_{\mathrm{x}}$ radicals, however, increase of $\mathrm{NO}_{\mathrm{x}}$ will suppress $\mathrm{O}_{3}$ formation due to titration reaction of $\mathrm{O}_{3}$ by $\mathrm{NO}$, while increase of VOCs will accelerate $\mathrm{O}_{3}$ formation by promoting the conversion rate of $\mathrm{NO}$ to $\mathrm{NO}_{2}$ because more $\mathrm{OH}$ radicals will react with VOCs through R1 to compete with R7. Therefore, the $\mathrm{H}_{2} \mathrm{O}_{2} / \mathrm{HNO}_{3}$ ratio is a good indicator for judging the relative roles of $\mathrm{H}_{2} \mathrm{O}_{2}$ and $\mathrm{HNO}_{3}$ in termination of $\mathrm{HO}_{\mathrm{x}}$ radicals and for assessment of the $\mathrm{VOCs}-\mathrm{NO}_{\mathrm{x}}-\mathrm{O}_{3}$ sensitivity (Hammer et al., 2002; Peng et al., 2006; Sillman, 1995; Sillman et al., 1998). Additionally, $\mathrm{H}_{2} \mathrm{O}_{2}$ also play a dominant role in sulfate formation through liquid-phase oxidation of sulfur dioxide $\left(\mathrm{SO}_{2}\right)$ in clouds, fogs, and deliquescent particles to account for acid deposition as well as deterioration of regional air quality (Calvert et al., 1985; Penkett et al., 1979; Shen et al., 2012; Ye et al., 2018). A recent study pointed out that the $\mathrm{SO}_{2}$ oxidation rate by $\mathrm{H}_{2} \mathrm{O}_{2}$ can be greatly enhanced in deliquesced aerosols with high solute strengths in comparison with dilute bulk aqueous solutions (T. Liu et al., 2020). Furthermore, $\mathrm{H}_{2} \mathrm{O}_{2}$ can pass into leaves or the human body to form liquid-phase free radical species (i.e., $\mathrm{OH}$ and $\mathrm{HO}_{2}$ ) for attacking nucleic acids and proteins leading to cell damage (Möller, 1989; Tao et al., 2003).

Considering the important roles of $\mathrm{H}_{2} \mathrm{O}_{2}$ in tropospheric chemistry as well as its adverse impact on the ecosystem, a growing number of measurements for atmospheric $\mathrm{H}_{2} \mathrm{O}_{2}$ have been reported in different places, including urban, rural and mountain sites as well as airborne measurements (Gong et al., 2018; Lee et al., 1997; Liang et al., 2013; Tanner \& Schorran, 1995; Walker et al., 2006; Wang et al., 2016; Watanabe et al., 2016; Zhang et al., 2018). In general, relatively high $\mathrm{H}_{2} \mathrm{O}_{2}$ levels (from several ppb to more than $10 \mathrm{ppb}$ ) usually occur in polluted regions or pollution plumes, for example, $\mathrm{H}_{2} \mathrm{O}_{2}$ mixing ratio up to $11.3 \mathrm{ppb}$ was observed in a seriously polluted rural site in China (Wang et al., 2016) and $11.5 \mathrm{ppb}$ in pollution plumes during flights in the marine troposphere (O'Sullivan et al., 1999). Photochemical pollution is severe in China especially in the North China Plain (NCP) and the surface $\mathrm{O}_{3}$ level has been found to exhibit a significant increasing trend of 1-2 $\mathrm{ppb} \mathrm{yr}^{-1}$ due to high anthropogenic emissions (Sun et al., 2016; Zhang et al., 2014). To our knowledge, $\mathrm{H}_{2} \mathrm{O}_{2}$ field measurements and analysis of $\mathrm{H}_{2} \mathrm{O}_{2}$ photochemistry in China are still scarce 
and thus urgently needed for a better understanding of tropospheric chemistry and $\mathrm{O}_{3}$ sensitivity to $\mathrm{NO}_{\mathrm{x}}$ or VOC emissions.

In this study, simultaneous observation of $\mathrm{H}_{2} \mathrm{O}_{2}$ and other relevant pollutants were performed at the foot of Mt. Tai in the summer of 2018 and at the summit of Mt. Tai in the summer of 2019 to explore $\mathrm{H}_{2} \mathrm{O}_{2}$ levels, variation characteristics and influencing factors. Based on the observational data measured at the foot of Mt. Tai, a zero-dimensional box model was employed to simulate the $\mathrm{H}_{2} \mathrm{O}_{2}$ budget. Additionally, $\mathrm{H}_{2} \mathrm{O}_{2}-\mathrm{O}_{3}$ correlation and the ratios of $\mathrm{H}_{2} \mathrm{O}_{2} / \mathrm{NO}_{\mathrm{z}}$ (the sum of reactive nitrogen compounds except for $\mathrm{NO}_{\mathrm{x}}$ ) were used to evaluate the VOCs- $\mathrm{NO}_{\mathrm{x}}-\mathrm{O}_{3}$ sensitivity.

\section{Materials and Methods}

\subsection{Field Study Site}

The mountain measurement was conducted at the Meteorological Observatory located at the summit of Mt. Tai $\left(36.25^{\circ} \mathrm{N}, 117.10^{\circ} \mathrm{E}, 1,534 \mathrm{~m}\right.$ a.s.l-above sea level, Figure S1) in Shandong province, China. Mt. Tai is located at the center of NCP. It is 15 and $30 \mathrm{~km}$ away from the Tai'an and Jinan city (the capital city of Shandong province), respectively. The altitude of the site is near the top of the boundary layer during the daytime in summer and in the residual layer at night. Studies have been conducted at this site to study cloud and particle chemistry and gas pollutants (Kanaya et al., 2013; Shen et al., 2012; Sun et al., 2016). This mountain site is thought to experience few local emission sources and provide regionally representative data for the NCP. The measurements took place from May to June in 2019.

The ground measurement took place from May to July 2018 at an urban site which located in Electric Power College in Tai'an City $\left(36.18^{\circ} \mathrm{N}, 117.11^{\circ} \mathrm{E}\right)$, about $10 \mathrm{~km}$ away from the foot of Mt. Tai. Tai'an city is located in central Shandong province at the eastern edge of the NCP, between the Bohai Economic Rim and Yangtze River Delta Economic Zone. Tai'an has a population of 15 million citizens. Recent years Tai'an city experiences serious $\mathrm{O}_{3}$ pollution in summer season.

\subsection{Instrumentation}

$\mathrm{H}_{2} \mathrm{O}_{2}$ was measured by a commercial monitor (AL2021, Aerolaser, Germany) based on wet chemical dual enzyme detection technique described by Lazrus et al. (1986). Gaseous $\mathrm{H}_{2} \mathrm{O}_{2}$ is sampled in buffered solution ( $\mathrm{pH}=5.8-6.0)$ in a glass stripping coil. Soluble organic peroxides can also dissolve into the stripping solution. After sampled by the stripping coil, the peroxides solution is divided into two channels and then reacts with $p$-hydroxyphenyl acetic acid (POPHA) and horseradish peroxidase. The reaction yields fluorescent dye which can be measured via fluorescence spectroscopy. Since all soluble peroxides can be detected by the reaction, one channel was added catalase prior to the reaction with POPHA in order to selectively destroy $\mathrm{H}_{2} \mathrm{O}_{2}$. The signal difference between the two channels represents the $\mathrm{H}_{2} \mathrm{O}_{2}$ concentrations. During the field campaigns, the liquid calibration was performed every 1 or 2 days with liquid $\mathrm{H}_{2} \mathrm{O}_{2}$ standards $\left(33.3 \mu \mathrm{g} \mathrm{L}^{-1}\right)$. The detection limit of the instrument is lower than 50 pptv with noise $<2 \%$ at full scale and has an uncertainty of 10\% (Fischer et al., 2015; Ye et al., 2018). The 1-min averages were recorded by a data logger. In this article, hourly averages were reported.

Measurements of HONO were conducted by a commercial LOPAP instrument (Long path absorption photometer, QUMA, Germany) which works based on a wet chemical technique (Heland et al., 2001). To avoid potential interferences induced by long inlet lines and heterogeneous or loss of HONO, HONO sampling unit was installed directly in the outdoor atmosphere. LOPAP collects HONO in stripping coil and then converts it into a dye which is detected using long path absorption. The instrument has two stripping coils placed in series to reduce known interfering signals.

A total of 56 non-methane hydrocarbons (NMHCs) were measured continuously and automatically using a liquid-nitrogen-free GC-FID instrument, with a time resolution of $1 \mathrm{~h}$. Detailed information about the GCFID can be found in C. Liu et al. (2016). The oxygenated volatile organic compounds (OVOCs) were sampled by adsorption-reaction cartridges with time resolution of $2 \mathrm{~h}$, and then analyzed by high liquid chromatography (HPLC) method. Air sample passed through an ozone scrubber and a Sep-Pak DNPH-Silica Cartridge 
Table 1

Comparison of the Observed Parameters at the Foot and Summit of Mt. Tai

\begin{tabular}{lcc}
\hline Parameters & Ground site & Mountain site \\
\hline Temperature $\left({ }^{\circ} \mathrm{C}\right)$ & $27.68 \pm 3.73$ & $16.20 \pm 3.35$ \\
$\mathrm{RH}(\%)$ & $49.46 \pm 17.79$ & $58.98 \pm 18.19$ \\
Wind speed $\left(\mathrm{m} \mathrm{s}^{-1}\right)$ & $1.93 \pm 0.97$ & $6.34 \pm 3.85$ \\
$\mathrm{NO}(\mathrm{ppb})$ & $1.88 \pm 6.96$ & $0.64 \pm 0.10$ \\
$\mathrm{NO}_{2}(\mathrm{ppb})$ & $14.49 \pm 9.59$ & $3.02 \pm 1.33$ \\
$\mathrm{O}_{3}(\mathrm{ppb})$ & $58.28 \pm 30.46$ & $74.53 \pm 12.06$ \\
$\mathrm{SO}_{2}(\mathrm{ppb})$ & $3.42 \pm 3.82$ & $1.23 \pm 0.66$ \\
$\mathrm{PM}_{2.5}(\mathrm{ppb})$ & $30.94 \pm 12.45$ & $29.12 \pm 19.28$ \\
$\mathrm{CO}_{(\mathrm{ppb})}$ & $263.1 \pm 230.6$ & $271.2 \pm 113.2$ \\
$\mathrm{H}_{2} \mathrm{O}_{2}(\mathrm{ppb})$ & $0.93 \pm 1.01$ & $2.05 \pm 1.20$ \\
\hline
\end{tabular}

and carbonyl compounds were trapped by cartridges. After sampling, the cartridges were brought to lab for elution using acetonitrile as eluent. The eluent solution was then injected in HPLC for analysis.

Trace gases including $\mathrm{NO}, \mathrm{NO}_{2}, \mathrm{SO}_{2}, \mathrm{O}_{3}$, and $\mathrm{CO}$ were measured by a series of online monitors. $\mathrm{NO}$ and $\mathrm{NO}_{2}$ were measured with the commercial Thermo Model 42i analyzer based on chemiluminescence technique. $\mathrm{SO}_{2}$ was measured by Thermo Model 43i using pulsed UV fluorescence. $\mathrm{O}_{3}$ measurements were performed based on UV absorption by the commercial Thermo 49i. Thermo 48i was used to measure CO. Multipoint calibration and zero and span checks were performed every week to ensure the data accuracy. Meteorological measurements (e.g., temperature, pressure, wind speed and direction, relative humidity, and solar radiation) were available from a potable weather station (Model WXT520, Vaisala, Finland) installed on the roof of a six-story teaching building near the sampling site.

\subsection{Box Model Setup}

A zero-dimensional box model using a near-explicit mechanism, MCM (Master Chemical Mechanism) Version 3.3.1 (Sommariva et al., 2020) was employed to examine the budget of atmospheric $\mathrm{H}_{2} \mathrm{O}_{2}$. The model treated the air pollutants to be wellmixed within the boundary layer and did not consider the dilution and transport. Simulations were only performed for the ground site due to the fact that the mountain site is greatly influenced by mountain-valley breeze, regional transport, and long-range transport (Kanaya et al., 2013; Ren et al., 2009) which could not be considered by the box model. MCMv3.3.1 describes the degradation of 143 VOCs with about 5,800 species and 17,000 reactions and has been extensively used in past studies of photochemistry. In our study, measurements of $\mathrm{NO}, \mathrm{NO}_{2}, \mathrm{O}_{3}, \mathrm{CO}$, NMHCs, OVOCs, $\mathrm{HONO}, \mathrm{H}_{2} \mathrm{O}$, temperature, pressure, and $\mathrm{j}\left(\mathrm{NO}_{2}\right)$ were used as inputs to constrain the model calculations. The model ran with a 1-h time step and a spin-up time of 2 days to reach a steady state. The boundary layer height was derived from the HYSPLIT model and varied between $1,500 \mathrm{~m}$ in daytime to $500 \mathrm{~m}$ in nighttime. Dry deposition loss in the box model was expressed as dry deposition velocity divided by boundary layer height.

\section{Results and Discussion}

\subsection{Meteorological and Chemical Conditions}

Figure S2 illustrated the time series of $\mathrm{H}_{2} \mathrm{O}_{2}$ and relevant parameters for the entire observation period at the foot of Mt. Tai. The comparison of observed parameters for both sites is shown in Table 1. The meteorological conditions at the foot of Mt. Tai during the observation period was characterized by high temperature (average: $27^{\circ} \mathrm{C}$; max: $37^{\circ} \mathrm{C}$ ), high relative humidity (average: $49 \%$; max: $90 \%$ ) and strong solar radiation (up to $800 \mathrm{~W} \mathrm{~m}^{-2}$ ), which favored the production of photochemical oxidants. The wind speeds were usually below $2 \mathrm{~m} \mathrm{~s}^{-1}$. Most of the days were sunny with exceptions of few rainy days (9 June, 25-26 June). During these rainy days, the maximum $\mathrm{O}_{3}$ concentrations were below $60 \mathrm{ppb}$. The back trajectory cluster analysis by HYSPLIT4 model (NOAA, USA, http://ready.arl.noaa.gov/HYSPLIT.php) showed that air mass arriving at the measurement site mainly came from the Shandong Peninsula and southern areas of Shandong province with large emissions of air pollutants (Figure S3). Relatively low NO levels during the whole period will be beneficial to the accumulation of $\mathrm{O}_{3}$ and $\mathrm{H}_{2} \mathrm{O}_{2}$. As shown in Figure $\mathrm{S} 2, \mathrm{O}_{3}$ hourly averaged levels frequently exceeded the Class-2 limit values $\left(160 \mu \mathrm{g} \mathrm{m}^{-3}\right.$ which is equivalent to $82 \mathrm{ppb}$ at $25^{\circ} \mathrm{C}$ and $\left.1,013 \mathrm{kPa}\right)$ of National Ambient Air Quality Standard of China (GB3095-2012), implying severe photochemical $\mathrm{O}_{3}$ pollution during summer season at Tai'an city. The particulate pollution was not severe with average concentrations of $30.9 \mu \mathrm{g} \mathrm{m}^{-3}$.

For the mountain site, the temperature during the observation period was much lower (average: $16.2^{\circ} \mathrm{C}$ ) than that at the ground site. The relative humidity was high with an average value of $59 \%$ as clouds and fog events occurred frequently at the mountain site in summer. High wind speed prevailed which suggested the 


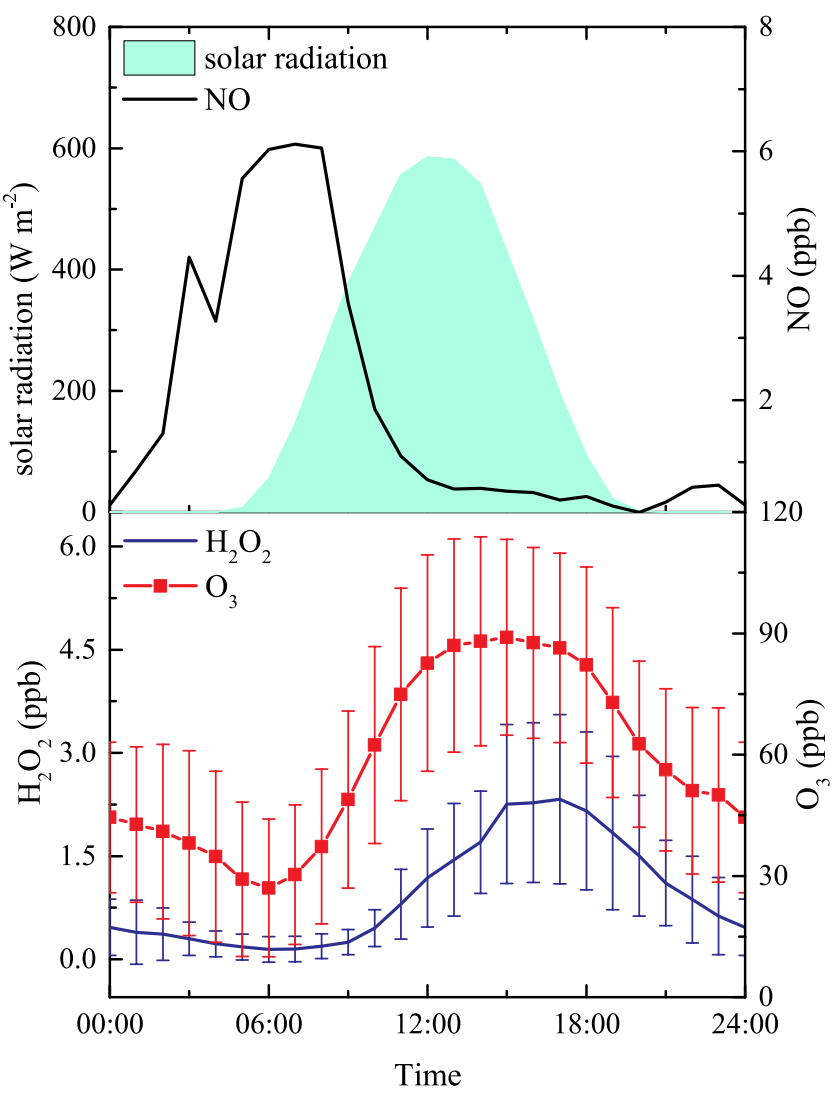

Figure 1. Average diurnal patterns for mixing ratios of $\mathrm{H}_{2} \mathrm{O}_{2}, \mathrm{O}_{3}, \mathrm{NO}$, and solar radiation at the foot of Mt. Tai. The vertical bars show standard errors for $\mathrm{H}_{2} \mathrm{O}_{2}$ and $\mathrm{O}_{3}$. site is easily influenced by transportation. Back trajectory cluster analysis showed air flow from Shandong Peninsula and southern areas where large city clusters are located dominated the air mass transport to the summit of Mt. Tai (Figure S3). This transport patterns are mainly driven by summer Asian monsoon (Ding et al., 2008; Sun et al., 2016). As Mt Tai is the highest mountain in the center of NCP and the summit is within the planetary boundary layer during daytime, the high-elevation site is regionally representative of the NCP where it is suffering from severe photochemical pollution during summer season. The average concentrations of primary pollutants $\mathrm{NO}(0.6 \mathrm{ppb}), \mathrm{NO}_{2}(3.0 \mathrm{ppb})$, and $\mathrm{SO}_{2}$ $(1.2 \mathrm{ppb})$ at the summit were lower than those at the ground site, which were $1.8 \mathrm{ppb}$ for $\mathrm{NO}, 14.4 \mathrm{ppb}$ for $\mathrm{NO}_{2}$, and $3.4 \mathrm{ppb}$ for $\mathrm{SO}_{2}$. $\mathrm{CO}(271 \mathrm{ppb}$ vs. $263 \mathrm{ppb})$ and $\mathrm{PM}_{2.5}\left(29.1 \mu \mathrm{g} \mathrm{m}^{-3}\right.$ vs. $\left.30.9 \mu \mathrm{g} \mathrm{m}^{-3}\right)$ were comparable at the two sites (Table 1).

\subsection{Diurnal Variations}

Obviously, a distinct $\mathrm{H}_{2} \mathrm{O}_{2}$ peak could be observed in each day at the foot of Mt. Tai, which was in line with the diurnal profiles of $\mathrm{O}_{3}$ and solar radiation (Figure S2). To clearly exhibit the relationship among $\mathrm{H}_{2} \mathrm{O}_{2}, \mathrm{O}_{3}, \mathrm{NO}$, and solar radiation at the foot of $\mathrm{Mt}$. Tai, their average diurnal variations are shown in Figure 1. The evident increase of both $\mathrm{H}_{2} \mathrm{O}_{2}$ and $\mathrm{O}_{3}$ mixing ratios from the morning to the afternoon verified that they were mainly from daytime photochemical reactions (Figure 1). Both $\mathrm{H}_{2} \mathrm{O}_{2}$ and $\mathrm{O}_{3}$ formations are directly related to the reactions of $\mathrm{HO}_{2}$ radicals which are formed by photolysis of carbonyls and the photooxidation of VOCs and $\mathrm{CO}$ initiated by $\mathrm{OH}$ radicals (R1-R3), resulting in their similar daytime increasing trends. Due to the effective suppression of $\mathrm{H}_{2} \mathrm{O}_{2}$ formation by $\mathrm{NO}$ (R5) in the early morning, growth of $\mathrm{H}_{2} \mathrm{O}_{2}$ mixing ratio commenced around 9:00 when NO concentration was less than $1 \mathrm{ppb}$, whereas a steep increase of $\mathrm{O}_{3}$ concentration occurred just after sunrise (around 6:00) when NO concentration was the highest (more than $6 \mathrm{ppb}$ ). In the morning, $\mathrm{O}_{3}$ formation is generally in the $\mathrm{NO}_{\mathrm{x}}$-saturated regime. When $\mathrm{NO}_{\mathrm{x}}$ began to decrease (time when $\mathrm{NO}$ was the highest), radical scavenging by $\mathrm{NO}_{x}$ oxidation to $\mathrm{HNO}_{3}$ weakened which led to more $\mathrm{O}_{3}$ production.

As solar radiation is the key precondition for triggering atmospheric photochemical reactions, the minimal $\mathrm{H}_{2} \mathrm{O}_{2}$ peak values ( $\sim 0.5 \mathrm{ppb}$ ) were observed on cloudy days (e.g., on 13 July) with weak solar radiation. Besides solar radiation, other factors also played important roles in $\mathrm{H}_{2} \mathrm{O}_{2}$ formation. For example, the $\mathrm{H}_{2} \mathrm{O}_{2}$ peak values varied from $\sim 2$ to $6 \mathrm{ppb}$ on the clear days with approximately the same solar radiation intensity, which was suspected to relate with the daily variations of $\mathrm{NO}_{\mathrm{x}}, \mathrm{VOCs}, \mathrm{CO}$, and the precursors of $\mathrm{OH}$ radicals that will be validated by the box model calculations constrained by the observational data in the following section. Although the uptake of $\mathrm{H}_{2} \mathrm{O}_{2}$ by particles during dust event has been proposed (de Reus et al., 2005; Qin et al., 2018), relatively high daytime $\mathrm{H}_{2} \mathrm{O}_{2}$ peak values ( $>2 \mathrm{ppb}$ ) were usually observed on the days when $\mathrm{PM}_{2.5}$ concentrations were higher than $40 \mu \mathrm{g} \mathrm{m}{ }^{-3}$, indicating that the promotion effect on $\mathrm{H}_{2} \mathrm{O}_{2}$ formation due to increase of VOCs, $\mathrm{CO}$ and $\mathrm{OH}$ precursors with the accumulation of $\mathrm{PM}_{2.5}$ greatly exceeded the $\mathrm{H}_{2} \mathrm{O}_{2}$ suppression effect by the $\mathrm{PM}_{2.5}$.

After reaching its maximum around 17:00, $\mathrm{H}_{2} \mathrm{O}_{2}$ started to decrease and maintained low concentrations (around the detection limit) throughout the night due to fast dry deposition loss. $\mathrm{O}_{3}$ concentrations also decreased in the late afternoon and frequently maintained high levels during the night (e.g., 3-8 June) which might be explained by lower dry deposition velocity than that of $\mathrm{H}_{2} \mathrm{O}_{2}$ (Crowley et al., 2018).

Figure 2 shows the average diurnal patterns of $\mathrm{H}_{2} \mathrm{O}_{2}$ and $\mathrm{O}_{3}$ observed at the summit of Mt. Tai. Time series of $\mathrm{H}_{2} \mathrm{O}_{2}$ and $\mathrm{O}_{3}$ were depicted in Figure $\mathrm{S} 4$. The $\mathrm{H}_{2} \mathrm{O}_{2}$ at the summit of Mt. Tai were highly variable with daily concentrations changing notably during the study period (Figure S4). This phenomenon could be explained by the influence of mountain-valley breeze and cloud scavenging. $\mathrm{H}_{2} \mathrm{O}_{2}$ has a high Henry Law constant 


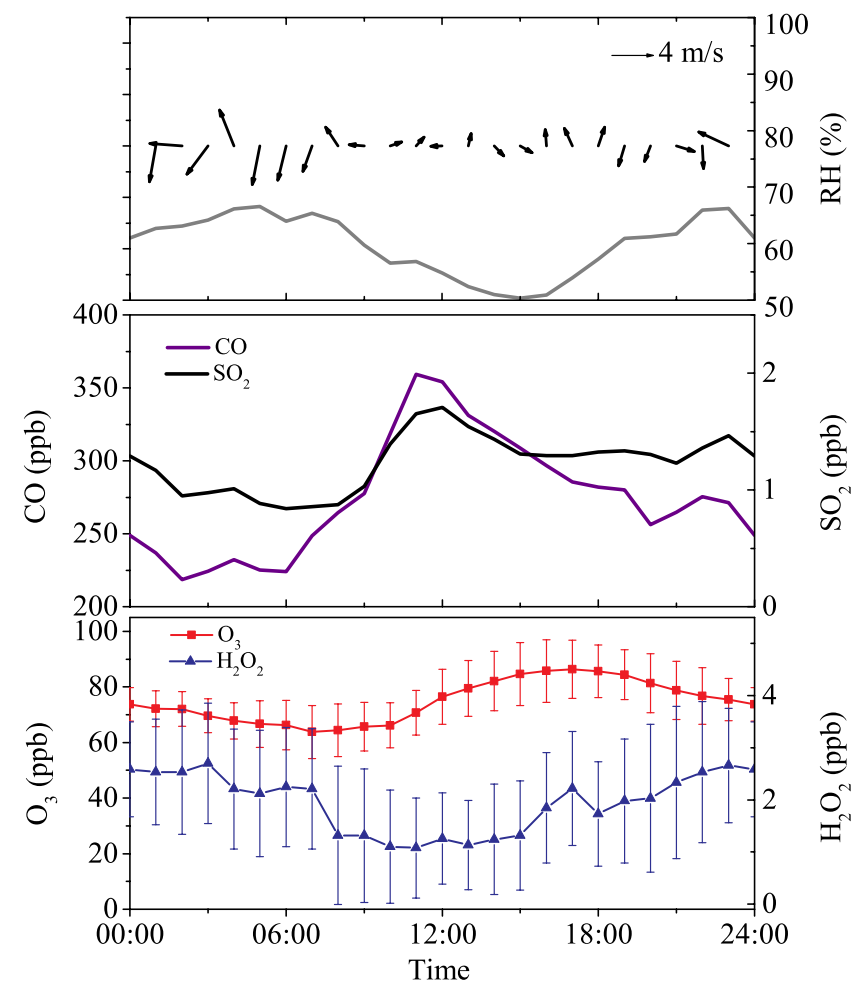

Figure 2. Average diurnal patterns of $\mathrm{H}_{2} \mathrm{O}_{2}, \mathrm{O}_{3}, \mathrm{CO}, \mathrm{SO}_{2}$, relative humidity $(\mathrm{RH})$, wind speed, and direction measured at the summit of Mt. Tai. $\left(1 \times 10^{5} \mathrm{M} \mathrm{atm}^{-1}\right)$ and hence is readily soluble in the liquid-phase. Consequently, gas-phase $\mathrm{H}_{2} \mathrm{O}_{2}$ concentrations are influenced by cloud and fog events. For example, during nighttime on 5 June (Figure S4), a sharp decrease of $\mathrm{H}_{2} \mathrm{O}_{2}$ coincided with an evident elevation of $\mathrm{RH}$ (up to 90\%), suggesting the uptake of $\mathrm{H}_{2} \mathrm{O}_{2}$ by cloud or fog droplets. Previous studies have reported high $\mathrm{H}_{2} \mathrm{O}_{2}$ concentrations in the cloud samples at the summit of Mt. Tai (Li et al., 2020; Shen et al., 2012), which mainly came from the wet removal of gas-phase $\mathrm{H}_{2} \mathrm{O}_{2}$. Assuming the $\mathrm{H}_{2} \mathrm{O}_{2}$ concentrations in cloud and Henry Law constant are $45.1 \mu \mathrm{M}$ (average value measured by $\mathrm{Li}$ et al. [2020]) and $1 \times 10^{5} \mathrm{M}$ atm $^{-1}$, respectively, then the gas-phase $\mathrm{H}_{2} \mathrm{O}_{2}$ concentrations are estimated to be $0.4 \mathrm{ppb}$, which is similar to the levels measured during the cloud event on 5 June. The high $\mathrm{H}_{2} \mathrm{O}_{2}$ detected in the cloud could also indicate high gas-phase $\mathrm{H}_{2} \mathrm{O}_{2}$ at the summit of Mt. Tai. It can be clearly seen that, from the average diurnal pattern in Figure $2, \mathrm{H}_{2} \mathrm{O}_{2}$ exhibited a broad minimum in daytime and then increased to maximum until midnight, which was a typical pattern observed at mountain sites (Balasubramanian \& Husain, 1997; Fischer et al., 2019; Ren et al., 2009). Obvious enhancements of primary pollutants $\left(\mathrm{CO}\right.$ and $\left.\mathrm{SO}_{2}\right)$ could be clearly seen after 6:00, which suggested the influence of upslope mountain-valley breeze and convective mixing. Additionally, the change of wind vector after 6:00 also indicated vertical transport by southerly and southwesterly airflows along the slope of the mountain. Therefore, the $\mathrm{H}_{2} \mathrm{O}_{2}$ and $\mathrm{O}_{3}$ increased during daytime, a process not only influenced by photochemical production but also upward transport from the foot of Mt. Tai by the mountain-valley breeze. Consistent phenomenon was also observed at the summit of Mt. Tai by previous studies (Cui et al., 2020; Gao et al., 2005; Ren et al., 2009). The increase lasted to the evening and then the concentrations of $\mathrm{O}_{3}$ and $\mathrm{H}_{2} \mathrm{O}_{2}$ remained nearly constant during the night. As the sampling site was in the residual layer at night, the dry deposition loss was minimized. In the early morning, with the development of the mixed layer, the mixing of $\mathrm{H}_{2} \mathrm{O}_{2}$ lead to a sharp drop of $\mathrm{H}_{2} \mathrm{O}_{2}$ concentrations at the high-elevation site.

Although the two measurements were both conducted in summer seasons, these measurements were done in different periods and different years, making it difficult to directly do comparison between the two sites. Nevertheless, we could have a preliminary analysis. As mentioned earlier, concentrations of primary pollutants at the summit were typically lower or comparable than those at the ground site, while the average concentrations of secondary pollutants like $\mathrm{H}_{2} \mathrm{O}_{2}$ and $\mathrm{O}_{3}$ were higher at the summit than at the foot of Mt. Tai (Table 1). This phenomenon of higher $\mathrm{H}_{2} \mathrm{O}_{2}$ and $\mathrm{O}_{3}$ concentrations at the summit could be explained by two possible reasons: the dry deposition loss and other sinks were minimized at the high-elevation site as the site was in the residual layer during the night and hence high night concentrations were preserved; in addition, $\mathrm{H}_{2} \mathrm{O}_{2}$ and $\mathrm{O}_{3}$ concentrations at the summit were greatly affected by regional transport from NCP areas, where are suffering from severe photochemical pollution in summer season.

\subsection{Comparison With Previous Studies}

In Table 2 we compare our observed $\mathrm{H}_{2} \mathrm{O}_{2}$ concentrations with those measured at ground and mountain sites in previous studies. Only summer data was summarized. For the measurements at ground level, the mean $\mathrm{H}_{2} \mathrm{O}_{2}$ concentration of $0.93 \mathrm{ppb}$ in the small city of Tai'an was evidently higher than those of the megacity of Beijing (0.20 ppb), Wangdu (0.51 ppb, a rural site in center of the Beijing-Tianjin-Hebei region), Southeastern tip of Hong Kong Island ( $0.29 \mathrm{ppb})$, Korea University ( $0.81 \mathrm{ppb})$, and Hyytiälä, Finland (0.382 ppb), but lower than that (1.26 ppb) of the megacity of Guangzhou. The lowest mean $\mathrm{H}_{2} \mathrm{O}_{2}$ concentration in Beijing city was probably ascribed to relatively high $\mathrm{NO}_{\mathrm{x}}$ concentrations which suppressed $\mathrm{H}_{2} \mathrm{O}_{2}$ formation, and the highest value in Guangzhou might be attributed to higher VOCs emissions especially for highly reactive biogenic VOCs because of high vegetation coverage, relatively high solar radiation intensity and temperature in the subtropical area. Although the latitude of the southeastern tip of Hong Kong Island 
Table 2

Summary of Some Gas-Phase $\mathrm{H}_{2} \mathrm{O}_{2}$ Measurements at Ground and Mountain Sites in Previous Studies

\begin{tabular}{|c|c|c|c|c|c|}
\hline & Measurement site & $\begin{array}{l}\text { Altitude } \\
(\mathrm{m})\end{array}$ & Period & $\mathrm{H}_{2} \mathrm{O}_{2}$ concentration (ppbv) & References \\
\hline \multirow[t]{9}{*}{ Ground sites } & Zion Supersite $\left(42.47^{\circ} \mathrm{N}, 87.81^{\circ} \mathrm{W}\right)$ & 160 & June 1-23, 2017 & $0.5-8$ (daytime) & Vermeuel et al. (2019) \\
\hline & Korea University $\left(37.35^{\circ} \mathrm{N}, 127.01^{\circ} \mathrm{E}\right)$ & 90 & June-August 2003 & Mean: $0.81(0.21-1.61)$ & Lee et al. (2008) \\
\hline & $\begin{array}{c}\text { University of Nevada }\left(39.55^{\circ} \mathrm{N},\right. \\
\left.119.82^{\circ} \mathrm{W}\right)\end{array}$ & 10 & June-December 1999 & $0.012-2.74$ & J. Liu et al. (2003) \\
\hline & Hyytiälä, Finland $\left(61.50^{\circ} \mathrm{N}, 24.17^{\circ} \mathrm{E}\right)$ & 181 & July 12-August 12, 2010 & $0.382(0.209-0.786)$ & Fischer et al. (2019) \\
\hline & $\begin{array}{l}\text { Southeastern tip of Hong Kong } \\
\text { Island }\left(22.21^{\circ} \mathrm{N}, 114.25^{\circ} \mathrm{E}\right)\end{array}$ & 60 & May 9-June 13, 2011 & $0.29 \pm 0.16$ & Guo et al. (2014) \\
\hline & Wangdu $\left(38.66^{\circ} \mathrm{N}, 115.25^{\circ} \mathrm{E}\right)$ & 35 & June 4-July 7, 2014 & Mean: $0.51(0.01-11.3)$ & Wang et al. (2016) \\
\hline & Beijing $\left(39.99^{\circ} \mathrm{N}, 116.30^{\circ} \mathrm{E}\right)$ & 53 & August 2010 & $0.20 \pm 0.28$ maximum: 1.59 & Liang et al. (2013) \\
\hline & Guangzhou $\left(23.54^{\circ} \mathrm{N}, 113.06^{\circ} \mathrm{E}\right)$ & 36 & July 18-30, 2006 & $\begin{array}{c}1.26 \pm 1.24 \text { (daytime) } \\
\text { maximum: } 4.6\end{array}$ & Hua et al. (2008) \\
\hline & Taian city $\left(36.18^{\circ} \mathrm{N}, 117.11^{\circ} \mathrm{E}\right)$ & 86 & May 30-July 13, 2018 & $0.93 \pm 1.01(0.1-6.06)$ & This study \\
\hline \multirow[t]{6}{*}{ Mountain sites } & Mt. Mitchell $\left(35.76^{\circ} \mathrm{N}, 82.26^{\circ} \mathrm{W}\right)$ & 2,006 & July-August 1988 & Mean: 0.76 maximum: 4.18 & Claiborn and Aneja (1991) \\
\hline & Mt. Norikura $\left(36.10^{\circ} \mathrm{N}, 137.55^{\circ} \mathrm{E}\right)$ & 2,770 & July-September 1993 & $0.1-4.5$ & Watanabe et al. (1995) \\
\hline & Mt. Whiteface $\left(43.93^{\circ} \mathrm{N}, 71.40^{\circ} \mathrm{W}\right)$ & 1,483 & July 1995 & $1.5-5.15$ & $\begin{array}{c}\text { Balasubramanian and } \\
\text { Husain (1997) }\end{array}$ \\
\hline & $\begin{array}{l}\text { Sky Forest, San Bernardino } \\
\text { Mountains }\left(34.12^{\circ} \mathrm{N}, 116.87^{\circ} \mathrm{W}\right)\end{array}$ & 1,790 & Spring through fall 1987-1990 & $0.79-3.25$ & $\begin{array}{l}\text { Sakugawa and } \\
\text { Kaplan (1993) }\end{array}$ \\
\hline & Mt. Tai $\left(36.26^{\circ} \mathrm{N}, 117.11^{\circ} \mathrm{E}\right)$ & 1,534 & June-July 2007 & $0.55 \pm 0.67$ & Ren et al. (2009) \\
\hline & Mt. Tai $\left(36.26^{\circ} \mathrm{N}, 117.11^{\circ} \mathrm{E}\right)$ & 1,534 & May-June 2019 & $2.05 \pm 1.20(0.05-5.36)$ & This study \\
\hline
\end{tabular}

is very close to Guangzhou city, the mean $\mathrm{H}_{2} \mathrm{O}_{2}$ concentration at the island was only one-fourth of that in Guangzhou city, further revealing that the photochemical processes in polluted areas are important sources for atmospheric $\mathrm{H}_{2} \mathrm{O}_{2}$. The mean $\mathrm{H}_{2} \mathrm{O}_{2}$ concentration at the foot of Mt. Tai was the highest among those measured at the places in the middle latitudes $\left(36^{\circ}-40^{\circ} \mathrm{N}\right)$, implying that the combined air pollution from anthropogenic and biogenic emissions might be in favor of $\mathrm{H}_{2} \mathrm{O}_{2}$ formation. The maximal daytime $\mathrm{H}_{2} \mathrm{O}_{2}$ value of $6.06 \mathrm{ppb}$ at the foot of Mt. Tai was at least a factor of 2 larger than those measured at various sampling sites, but lower than those measured in Zion Supersite (8 ppb) and Wangdu (11.3 ppb).

For the mountain measurements with altitudes ranging from 1,483 to $2,770 \mathrm{~m}$, the mean $\mathrm{H}_{2} \mathrm{O}_{2}$ concentration (2.05 ppb) and maximal $\mathrm{H}_{2} \mathrm{O}_{2}$ concentration (5.36 ppb) measured at the summit of Mt. Tai in our study was the highest among those reported in the literature. For the same sampling site at the summit of Mt. Tai, the mean $\mathrm{H}_{2} \mathrm{O}_{2}$ concentration measured by this study was about a factor of 3 greater than that measured during the period of June-July in 2007. Zhou et al. (2019) found that tropospheric column HCHO from satellite observations, which is indicative of the change of reactive VOCs, showed an increase of $0.05 \times 10^{15}$ molecules $\mathrm{cm}^{-2} \mathrm{yr}^{-1}$ during the whole period from 2005 to 2016 in the NCP. Therefore, the remarkable increase of $\mathrm{H}_{2} \mathrm{O}_{2}$ from 2007 to 2019 at the summit of Mt. Tai might be ascribed to the increase of VOCs emissions. Moreover, since China launched the toughest-ever clean air action plan to resolve serious pollution issues in 2013, $\mathrm{SO}_{2}$ concentrations in 2017 decreased by $66 \%$ compared to the 2013 level in Beijing-Tianjin-Hebei area, which resulted in a $49 \%$ reduction in sulfate concentrations (Geng et al., 2019). $\mathrm{H}_{2} \mathrm{O}_{2}$ is one of the most important oxidants for liquid-phase $\mathrm{SO}_{2}$ oxidation and hence $\mathrm{SO}_{2}$ reduction would lead to less $\mathrm{H}_{2} \mathrm{O}_{2}$ consumption, especially for the mountain site where the clouds events frequently occur. A recent study reported an increasing trend of $\mathrm{H}_{2} \mathrm{O}_{2}$ concentrations in the cloud samples at the summit of Mt. Tai from 2014 to 2018 (Li et al., 2020), which suggested less $\mathrm{SO}_{2}$ consumption of $\mathrm{H}_{2} \mathrm{O}_{2}$ and the increase of gas-phase $\mathrm{H}_{2} \mathrm{O}_{2}$ concentrations at a certain degree. Therefore, both VOCs increase and $\mathrm{SO}_{2}$ reductions are the potential driving factors leading to much higher gas-phase $\mathrm{H}_{2} \mathrm{O}_{2}$ concentrations than 10 years ago at the summit of Mt. Tai. 


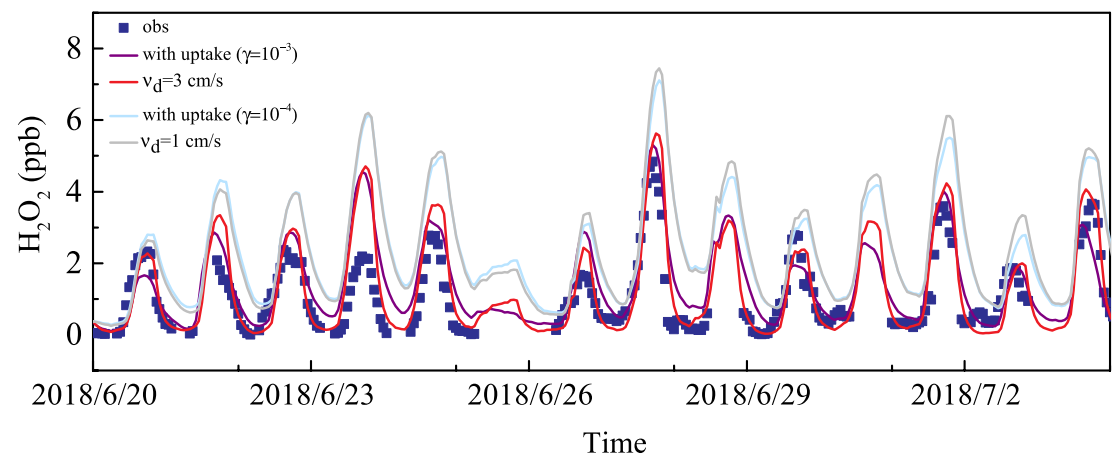

Figure 3. Observed and modeled $\mathrm{H}_{2} \mathrm{O}_{2}$ concentrations from June 20 to July 3, 2018 at the foot of Mt. Tai. The blue dots represent the measured concentrations. The red and gray lines represent the modeled results with dry deposition velocity of 3 and $1 \mathrm{~cm} \mathrm{~s}^{-1}$, respectively. The purple and light blue lines represent modeled results with uptake coefficient of $1 \times 10^{-3}$ and $1 \times 10^{-4}$, respectively.

\subsection{The Sources and Sinks for $\mathrm{H}_{2} \mathrm{O}_{2}$}

To disclose the reason for the relatively high atmospheric $\mathrm{H}_{2} \mathrm{O}_{2}$ concentration at the foot of Mt. Tai, a box model based on the Master Chemical Mechanism (MCM Version 3.3.1) was employed for preliminarily exploring the sources and sinks of the $\mathrm{H}_{2} \mathrm{O}_{2}$. In the initial running, $\mathrm{H}_{2} \mathrm{O}_{2}$ dry deposition velocity was set as $1 \mathrm{~cm} \mathrm{~s}^{-1}$ which was commonly used in box model simulations (Guo et al., 2014; Qin et al., 2018). As shown in Figure 3 (gray line), the modeling results could well reproduce the daily variation trend of $\mathrm{H}_{2} \mathrm{O}_{2}$, but both the $\mathrm{H}_{2} \mathrm{O}_{2}$ peak values in the daytime and minimal values at night were significantly overestimated $\left(\mathrm{H}_{2} \mathrm{O}_{2}\right.$ modeled $/ \mathrm{H}_{2} \mathrm{O}_{2}$ measured $=1.8$ ), indicating that the sink for $\mathrm{H}_{2} \mathrm{O}_{2}$ might be largely underestimated. Some laboratory studies found that heterogeneous uptake by particles could be a sink for $\mathrm{H}_{2} \mathrm{O}_{2}$ (Pradhan et al., 2010; Romanias et al., 2012; Zhao et al., 2011). If the uptake coefficient of $1 \times 10^{-4}$ was considered, $\mathrm{H}_{2} \mathrm{O}_{2}$ concentrations throughout the whole period were overestimated (light blue line in Figure 3). When the upper limit of $\mathrm{H}_{2} \mathrm{O}_{2}$ uptake coefficients $\left(10^{-5}-10^{-3}\right)$ by particles derived from lab experiments were adopted (Pradhan et al., 2010; Romanias et al., 2012; Zhao et al., 2011), however, the simulated $\mathrm{H}_{2} \mathrm{O}_{2}$ concentrations were still overestimated especially during nighttime (the purple line in Figure 3). If the dry deposition velocity of $1 \mathrm{~cm} \mathrm{~s}^{-1}$ in the model was replaced by $3 \mathrm{~cm} \mathrm{~s}^{-1}$, good agreement between the modeled and measured $\mathrm{H}_{2} \mathrm{O}_{2}$ could be achieved (the red line in Figure 3). The fast $\mathrm{H}_{2} \mathrm{O}_{2}$ dry deposition loss at the foot of Mt. Tai could be reflected by the high first-order decay rate constant $\left(k_{\mathrm{d}}=6 \times 10^{-5} \mathrm{~s}^{-1}\right)$ of $\mathrm{H}_{2} \mathrm{O}_{2}$, which was derived by fitting the exponential decay curve (Figure S5) to the hourly averaged $\mathrm{H}_{2} \mathrm{O}_{2}$ concentrations from 19:00 to 6:00 according to the following equation:

$$
k_{\mathrm{d}}=\frac{\ln C_{0}-\ln C}{t}
$$

where, $C_{0}$ is the $\mathrm{H}_{2} \mathrm{O}_{2}$ concentration at $t=0 \mathrm{~s}$, while $C$ is the $\mathrm{H}_{2} \mathrm{O}_{2}$ concentration at $t$, and the slope of the linear regression of $\left(\ln C_{0}-\ln C\right)$ versus time $t$ represents $k_{\mathrm{d}}$.

Because the possible sinks of atmospheric $\mathrm{H}_{2} \mathrm{O}_{2}$ through photochemical reactions (e.g., the photolysis of $\mathrm{H}_{2} \mathrm{O}_{2}$ and its reaction with $\mathrm{OH}$ radicals) ceased at night, the $\mathrm{H}_{2} \mathrm{O}_{2}$ decay during the selected period was mainly ascribed to dry deposition. Then the dry deposition velocity $\left(v_{\mathrm{d}}\right.$ in unit of $\mathrm{cm} \mathrm{s}^{-1}$ ) of $\mathrm{H}_{2} \mathrm{O}_{2}$ could be estimated according to the following equation (Shepson et al., 1992):

$$
v_{\mathrm{d}}=k_{\mathrm{d}} \times \mathrm{BLH}
$$

Based on typical boundary layer heights (BLH) of 300-500 $\mathrm{m}$ at night in summer seasons (Tang et al., 2016; Zhu et al., 2018), $v_{\mathrm{d}}$ value was estimated to be $1.8-3 \mathrm{~cm} \mathrm{~s}^{-1}$ which was in the range of $1-5 \mathrm{~cm} \mathrm{~s}^{-1}$ reported in previous studies (Crowley et al., 2018; Fischer et al., 2019; Hall \& Claiborn, 1997; Liang et al., 2013; Nguyen et al., 2015), but higher than the commonly used value of $1 \mathrm{~cm} \mathrm{~s}^{-1}$ in model simulations. Additionally, the reactions of alkenes with $\mathrm{O}_{3}$ also contributed to nighttime $\mathrm{H}_{2} \mathrm{O}_{2}$ at the foot, and thus the $v_{\mathrm{d}}$ value obtained from the $\mathrm{H}_{2} \mathrm{O}_{2}$ decay at night in this study may only represent a lower limit of the $\mathrm{H}_{2} \mathrm{O}_{2}$ dry deposition velocity. Therefore, the upper $v_{\mathrm{d}}$ value of $3 \mathrm{~cm} \mathrm{~s}^{-1}$ estimated might be reasonable for the model simulation, 


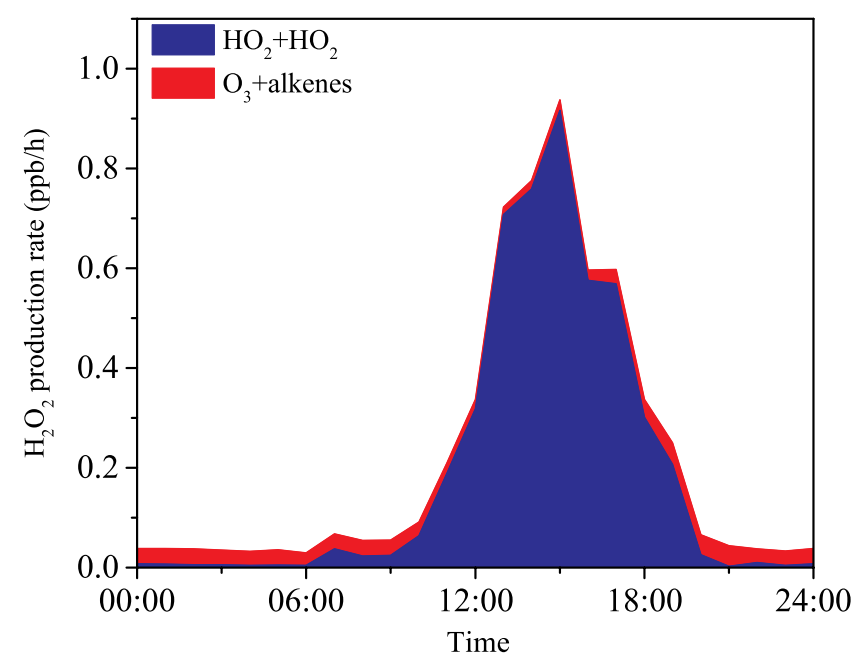

Figure 4. Modeled sources of $\mathrm{H}_{2} \mathrm{O}_{2}$ from June 20 to July 3, 2018. resulting in the good agreement between the modeled and measured $\mathrm{H}_{2} \mathrm{O}_{2}$. Above results indicated $\mathrm{H}_{2} \mathrm{O}_{2}$ dry deposition velocity of $1 \mathrm{~cm} \mathrm{~s}^{-1}$ in box models might be underestimated. A recent study also suggested that 3D chemical transport models like GEOS-Chem model underestimated $\mathrm{H}_{2} \mathrm{O}_{2}$ dry deposition velocity which resulted in an enhancement of the simulated $\mathrm{H}_{2} \mathrm{O}_{2}$ surface concentrations by $45 \%$ (Nguyen et al., 2015). It should be pointed out that, however, the gas-phase model in our study did not consider the wet removal of $\mathrm{H}_{2} \mathrm{O}_{2}$ which may also bring some uncertainty to the dry deposition value. Nevertheless, the high dry deposition value estimated from our field measurements and modeling at least implied there existed a large sink of $\mathrm{H}_{2} \mathrm{O}_{2}$ near the ground at Tai'an city. Dry deposition velocity is closely related to the type of terrestrial surfaces and varies from site to site. Therefore, a fixed value may not be representative for one place to another. For example, higher dry deposition velocities were usually found in the forests (Hall \& Claiborn 1997; Valverde-Canossa et al., 2006), where the underlying surface resistance is typically smaller. Uncertainties in the dry deposition velocity limit the simulations of $\mathrm{H}_{2} \mathrm{O}_{2}$ and its budget predictions in the troposphere. The need is high for more field observations to constrain the dry deposition parameterization and its input data to improve the use of air quality models for the public.

In addition to the self-combination of $\mathrm{HO}_{2}$ radicals for $\mathrm{H}_{2} \mathrm{O}_{2}$ formation, the ozonolysis of alkenes has also been considered as an important source for atmospheric $\mathrm{H}_{2} \mathrm{O}_{2}$. This reaction produces Criegee intermediates, which then react with water vapor under atmospheric conditions yielding hydroxyalkyl hydroperoxides and subsequent decomposition leads to the formation of $\mathrm{H}_{2} \mathrm{O}_{2}$ (Valverde-Canossa et al., 2001). $\mathrm{H}_{2} \mathrm{O}_{2}$ production rates from the above two sources are illustrated in Figure 4. It is evident that the ozonolysis of alkenes acted as the dominant source for atmospheric $\mathrm{H}_{2} \mathrm{O}_{2}$ at night, whereas the self-combination of $\mathrm{HO}_{2}$ accounted for more than $87 \%$ of the total production rate of $\mathrm{H}_{2} \mathrm{O}_{2}$ in the daytime. Three kinds of sinks for atmospheric $\mathrm{H}_{2} \mathrm{O}_{2}$ were considered in the model simulation: photolysis, reaction with $\mathrm{OH}$ radicals and dry deposition loss. The former two sinks only occur in the daytime, whereas the last one happens in both daytime and nighttime. Modeling results showed that $\mathrm{H}_{2} \mathrm{O}_{2}$ dry deposition was the dominant sink with a contribution of $84 \%$ to the total, followed by the reaction of $\mathrm{H}_{2} \mathrm{O}_{2}$ with $\mathrm{OH}(11 \%)$ and $\mathrm{H}_{2} \mathrm{O}_{2}$ photolysis (5\%).

Atmospheric $\mathrm{HO}_{2}$ radicals mainly come from the photooxidation processes of VOCs and CO, and thus a relative incremental reactivity (RIR) method (Cardelino \& Chameides, 1995) was employed for exploring the relative contributions of VOCs species and $\mathrm{CO}$ to atmospheric $\mathrm{H}_{2} \mathrm{O}_{2}$. For a specific precursor of $X$, $\mathrm{RIR}_{X}$ is defined as following formula:

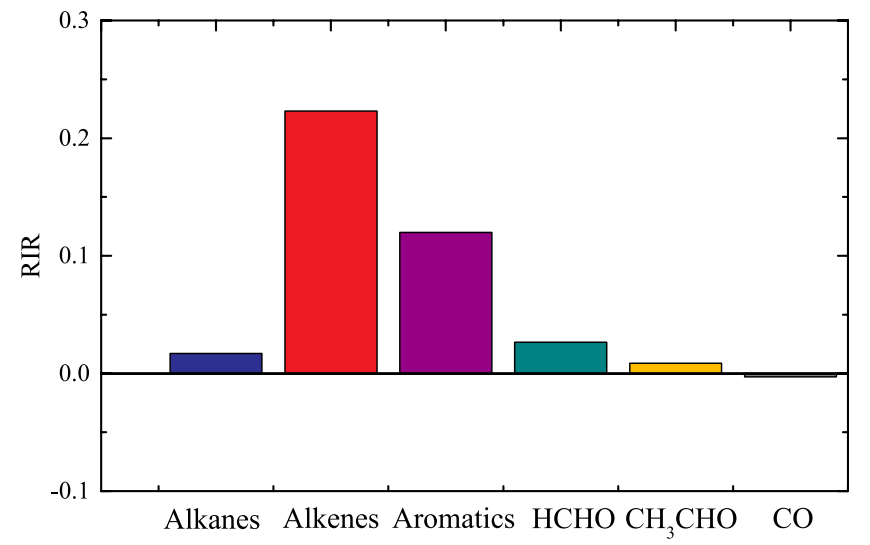

Figure 5. Sensitivity of $\mathrm{H}_{2} \mathrm{O}_{2}$ production to major VOC precursor groups, individual OVOC species and $\mathrm{CO}$.

$$
\operatorname{RIR}_{(X)}=\frac{C\left(S_{(X)}\right)-C\left(S_{(X-\Delta x)}\right)}{C\left(S_{(X)}\right)}
$$

where, $C\left(S_{(X)}\right)$ represents the $\mathrm{H}_{2} \mathrm{O}_{2}$ concentration when its precursor concentration was $S(X), C(S(X-\Delta X))$ represents the $\mathrm{H}_{2} \mathrm{O}_{2}$ concentration when its precursor concentration was reduced from $S(X)$ to $S(X-\Delta X)$.

In this study, the atmospheric concentrations of alkanes, alkenes, aromatics, $\mathrm{HCHO}, \mathrm{CH}_{3} \mathrm{CHO}$, and $\mathrm{CO}$ were respectively reduced by $30 \%$ for exploring their relative contributions to atmospheric $\mathrm{H}_{2} \mathrm{O}_{2}$. As shown in Figure 5, the reduction of alkenes resulted in the highest RIR value of 0.223 , followed by aromatics (0.125), HCHO (0.026), alkanes (0.017), $\mathrm{CH}_{3} \mathrm{CHO}(0.008)$, and $\mathrm{CO}(-0.003)$. As alkenes and aromatics have higher photochemical reactivities relative to other VOC species, reduction of alkenes and aromatics lead to the more pronounced decrease of $\mathrm{H}_{2} \mathrm{O}_{2}$. Additionally, because of the double-bonded carbon atoms in alkene 

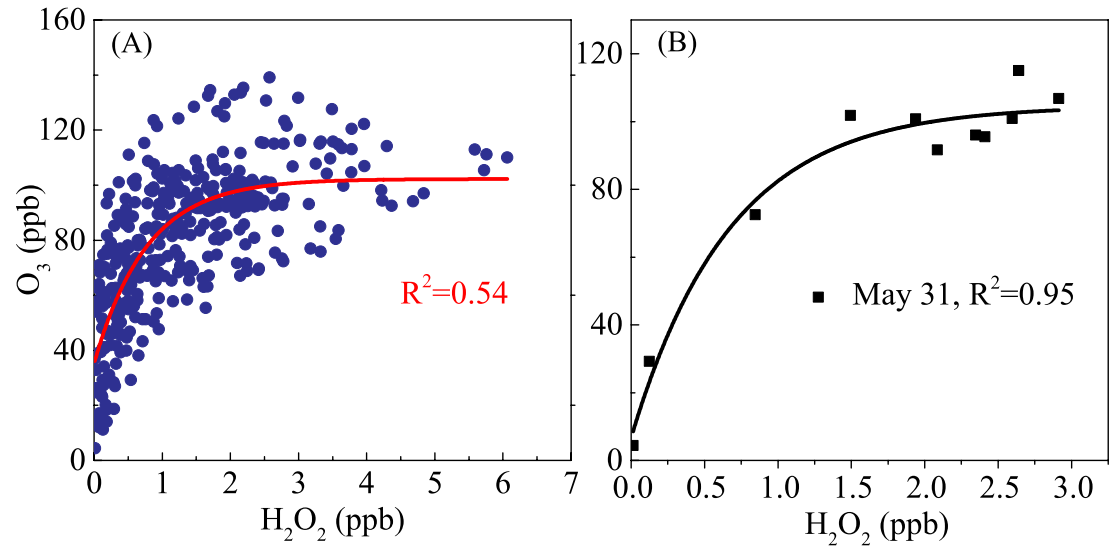

Figure 6. Correlation between hourly averaged $\mathrm{H}_{2} \mathrm{O}_{2}$ and $\mathrm{O}_{3}$ concentrations from 8:00 to 18:00. (a) The period from May 30 to July 15, 2018. (b) Day on May 31.

molecules, they will also react with $\mathrm{O}_{3}$ and $\mathrm{NO}_{3}$ radical to produce $\mathrm{HO}_{\mathrm{x}}$ radicals and subsequent $\mathrm{H}_{2} \mathrm{O}_{2}$ formation (Becker et al., 1993). Although the reaction of $\mathrm{CO}$ with $\mathrm{OH}$ produces $\mathrm{HO}_{2}$ radicals, the $\mathrm{OH}$ consumption by atmospheric CO may slightly suppress the photochemical reactions of VOCs leading to less overall $\mathrm{HO}_{2}$ production. Besides the formation of $\mathrm{HO}_{2}$ radicals from the direct reactions of VOCs with $\mathrm{OH}$, additional $\mathrm{HO}_{2}$ can be produced through photolysis of the major products of carbonyls from the reactions, and thus $\mathrm{CO}$ reduction resulted in a small negative value of RIR. The large difference of RIR values among the VOCs species or classified compounds was mainly ascribed to their different photochemical reactivities. Although alkanes were the most abundant species, their reaction rate constants with $\mathrm{OH}$ radicals are usually 1-3 magnitudes slower than those of alkenes and aromatics (Atkinson et al., 2001), resulting in relatively small RIR values. The reaction rate constant of $\mathrm{CH}_{3} \mathrm{CHO}\left(1.5 \times 10^{-11} \mathrm{~cm}^{3}\right.$ molecule $\left.{ }^{-1} \mathrm{~s}^{-1}\right)$ with $\mathrm{OH}$ radicals was nearly twice as that of $\mathrm{HCHO}\left(8.5 \times 10^{-12} \mathrm{~cm}^{3}\right.$ molecule $\left.\mathrm{s}^{-1}\right)$ at $298 \mathrm{~K}$ (Atkinson et al., 2001), but the RIR value of $\mathrm{HCHO}$ was about a factor of 3 greater than that of $\mathrm{CH}_{3} \mathrm{CHO}$. Besides the $\mathrm{OH}$-initiated reactions, photolysis of the aldehydes is also an important source for $\mathrm{HO}_{2}$ radicals, for example, the photolysis of $\mathrm{HCHO}$ can produce fragments of $\mathrm{H}$ and $\mathrm{HCO}$ which readily react with $\mathrm{O}_{2}$ to form two $\mathrm{HO}_{2}$ radicals (Bufalini et al., 1972). Because the photolysis rate of $\mathrm{HCHO}$ is usually at least one magnitude greater than that of $\mathrm{CH}_{3} \mathrm{CHO}$ under sunlight irradiation (Pang \& Mu, 2006), the relatively high RIR for HCHO indicated its photolysis made a significant contribution to atmospheric $\mathrm{HO}_{2}$ radicals. On the other hand, the $\mathrm{HO}_{2}$ radicals formed from $\mathrm{HCHO}$ photolysis will partially be involved in the reaction with NO in polluted areas to recycle $\mathrm{OH}$ radicals which further initiate VOCs oxidation for more $\mathrm{HO}_{2}$ formation.

As the photochemical reactions of VOCs initiated by $\mathrm{OH}$ radicals play key roles in $\mathrm{H}_{2} \mathrm{O}_{2}$ formation, the $\mathrm{OH}$ primary sources at the foot of Mt. Tai were also investigated by modeling calculations. $\mathrm{O}_{3}$ and $\mathrm{HONO}$ are direct contributors to $\mathrm{OH}$ radicals. Since $\mathrm{HCHO}$ photolysis leads to $\mathrm{HO}_{2}$ production and subsequent reaction with $\mathrm{NO}$ also yields $\mathrm{OH}$ radicals, $\mathrm{O}_{3}, \mathrm{HONO}$, and $\mathrm{HCHO}$ were all taken into consideration. As shown in Figure S6, the photolysis of $\mathrm{O}_{3}$ was the dominant source for $\mathrm{OH}$ radicals, with a maximal $\mathrm{OH}$ production rate of $3.37 \mathrm{ppb} \mathrm{h}^{-1}$ at noontime, followed by photolysis of $\operatorname{HCHO}\left(2.91 \mathrm{ppb} \mathrm{h}^{-1}\right)$ and $\operatorname{HONO}\left(1.35 \mathrm{ppb} \mathrm{h}^{-1}\right)$.

Taking both the RIR values for the individual species and $\mathrm{OH}$ sources into account, the most efficient control measures for mitigating the $\mathrm{H}_{2} \mathrm{O}_{2}$ level at the ground site are the reduction of alkenes, aromatics and $\mathrm{O}_{3}$ concentrations. Alkenes and aromatics reduction can be easily achieved through reducing their emission sources, but the reduction of $\mathrm{O}_{3}$ should first assess the sensitive chemistry of $\mathrm{O}_{3}$ formation which has a non-linear correlation with its precursors of VOCs and $\mathrm{NO}_{\mathrm{x}}$.

\subsection{The Sensitive Chemistry for $\mathrm{O}_{3}$ Formation}

To explore the sensitive chemistry for $\mathrm{O}_{3}$ formation at the ground site, the correlation between hourly averaged $\mathrm{H}_{2} \mathrm{O}_{2}$ and $\mathrm{O}_{3}$ concentrations from 8:00 to 18:00 measured during the whole observation period and in a typical clear day are illustrated in Figure 6. When $\mathrm{H}_{2} \mathrm{O}_{2}$ was below $0.5 \mathrm{ppb}$, which mainly occurred in 


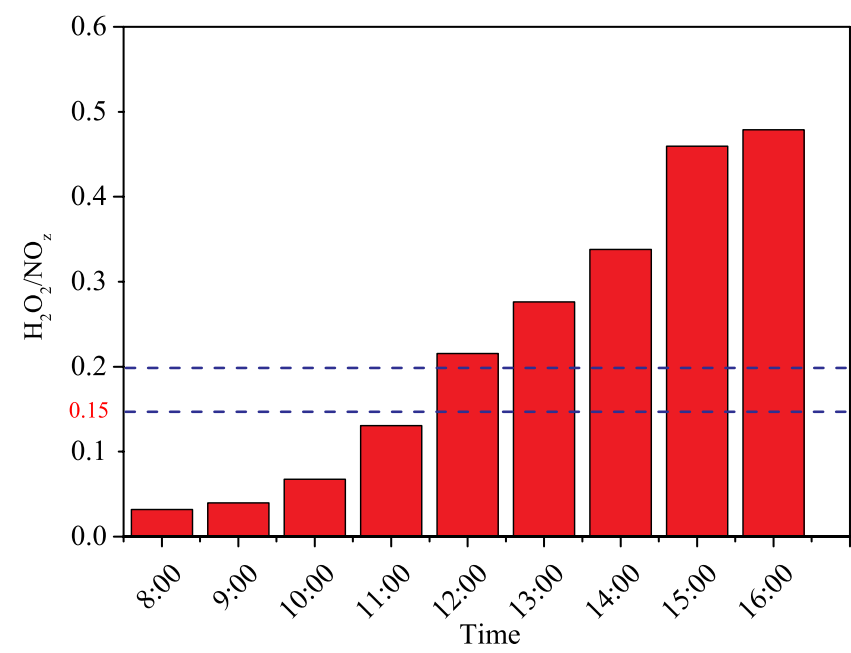

Figure 7. Average diurnal pattern of $\mathrm{H}_{2} \mathrm{O}_{2} / \mathrm{NO}_{z}$ ratio from 8:00 to $16: 00$ during the whole period. the early morning hours, $\mathrm{O}_{3}$ mixing ratio steeply increased with slight $\mathrm{H}_{2} \mathrm{O}_{2}$ elevation and $\Delta \mathrm{O}_{3} / \Delta \mathrm{H}_{2} \mathrm{O}_{2}$ was usually $>80$, indicating that most of the $\mathrm{HO}_{2}$ radicals formed from photochemical reactions of VOCs were involved in the conversion of $\mathrm{NO}$ to $\mathrm{NO}_{2}$ and then generated $\mathrm{O}_{3}$, namely $\mathrm{O}_{3}$ formation is sensitive to VOCs. Whereas when $\mathrm{H}_{2} \mathrm{O}_{2}$ was greater than $1 \mathrm{ppb}$, which mainly appeared in the early afternoon, $\mathrm{O}_{3}$ mixing ratio slowly increased or even remained constant with significantly increasing $\mathrm{H}_{2} \mathrm{O}_{2}$, revealing that most of the $\mathrm{HO}_{2}$ radicals were involved in $\mathrm{H}_{2} \mathrm{O}_{2}$ formation through their recombination channel, that is, $\mathrm{O}_{3}$ formation was sensitive to $\mathrm{NO}_{\mathrm{x}}$.

To further verify the above conclusions about $\mathrm{O}_{3}$ sensitive chemistry, the average $\mathrm{H}_{2} \mathrm{O}_{2} / \mathrm{NO}_{\mathrm{z}}$ ratios during daytime were also analyzed, which are illustrated in Figure 7. Like the $\mathrm{H}_{2} \mathrm{O}_{2} / \mathrm{HNO}_{3}$ ratio, $\mathrm{H}_{2} \mathrm{O}_{2} / \mathrm{NO}_{\mathrm{z}}$ ratio is also widely used as an indicator for diagnosing the VOCs- $\mathrm{NO}_{\mathrm{x}}-\mathrm{O}_{3}$ sensitive chemistry (Castell et al., 2009; Reeves \& Penkett, 2003; Sillman, 1995). $\mathrm{NO}_{z}$ is the sum of reactive nitrogen compounds which are the products from atmospheric conversion of $\mathrm{NO}_{\mathrm{x}}$, including $\mathrm{HNO}_{3}$, nitrous acid (HONO), peroxyacetyl nitrates (PAN), organic nitrates, etc. In this study, the threshold values of $\mathrm{H}_{2} \mathrm{O}_{2} / \mathrm{NO}_{\mathrm{z}}=0.15-0.20$ which are derived from model simulations (Sillman, 1995; Sillman et al., 1995, 1998), are adopted for judging the VOCs- $\mathrm{NO}_{\mathrm{x}}-\mathrm{O}_{3}$ sensitive chemistry, that is,: the $\mathrm{H}_{2} \mathrm{O}_{2} / \mathrm{NO}_{\mathrm{z}}$ ratios below, above and within the threshold values represent a VOC-sensitive regime, a $\mathrm{NO}_{\mathrm{x}}$-sensitive regime and a transition regime, respectively. The ratio was below 0.15 from 8:00 to 11:00 and above 0.2 from 12:00 to 16:00, implying that $\mathrm{O}_{3}$ formation in Taian city was sensitive to VOCs in the morning hours and switched to $\mathrm{NO}_{\mathrm{x}}$-sensitive around noontime. The above-mentioned results are also consistent with other observations. For example, measured $\mathrm{H}_{2} \mathrm{O}_{2}$ concentrations in our study are comparable with those measured in other sites that are found to be mainly $\mathrm{NO}_{\mathrm{x}}$-sensitive, such as in Nashville, Tennessee (Weinstein-Lloyd et al., 1998). In addition, the measured $\mathrm{H}_{2} \mathrm{O}_{2}$ concentrations are much higher than those measured in locations which are believed to be mainly VOC-sensitive, like in Beijing city (He et al., 2010).

\section{Conclusions}

In this study, atmospheric $\mathrm{H}_{2} \mathrm{O}_{2}$ mixing ratios were measured at the foot of Mt. Tai in the summer of 2018 and at the summit of Mt. Tai in the summer of 2019, with average values of $0.93 \pm 1.01$ and $2.05 \pm 1.20 \mathrm{ppb}$, respectively. The significantly high $\mathrm{H}_{2} \mathrm{O}_{2}$ levels in Tai'an city in comparison with the cities at approximately the same middle latitude implied that the photochemical pollution in the city is very serious. Compared with the measurements in summer of 2007, the remarkable elevation of $\mathrm{H}_{2} \mathrm{O}_{2}$ at the summit of Mt. Tai might be ascribed to VOCs increase and $\mathrm{SO}_{2}$ decline in recent years. $\mathrm{H}_{2} \mathrm{O}_{2}$ exhibited a pronounced diurnal variation and reverse pattern with $\mathrm{NO}$ levels at the foot of Mt. Tai. With $\mathrm{H}_{2} \mathrm{O}_{2}$ dry deposition velocity of $3 \mathrm{~cm} \mathrm{~s}^{-1}$ included, the observed $\mathrm{H}_{2} \mathrm{O}_{2}$ concentrations at the foot of Mt. Tai could be well reproduced by a gas-phase box model, indicating $\mathrm{H}_{2} \mathrm{O}_{2}$ was mainly photochemically produced. Modeling analysis showed that the source and sink of $\mathrm{H}_{2} \mathrm{O}_{2}$ were dominated by $\mathrm{HO}_{2}$ recombination and dry deposition loss, respectively. $\mathrm{H}_{2} \mathrm{O}_{2}$ production at the foot was found to be most sensitive to alkenes and aromatics by sensitivity tests, which demonstrated reducing alkenes and aromatics emissions were most efficient to decrease $\mathrm{H}_{2} \mathrm{O}_{2}$ concentrations. The evaluation of sensitive chemistry of $\mathrm{O}_{3}$ in Tai'an city well elucidated that $\mathrm{O}_{3}$ formation was VOC-sensitive in the early morning and shifted to $\mathrm{NO}_{\mathrm{x}}$-sensitive thereafter. Therefore, reduction of VOCs emissions especially for the reactive species of alkenes and aromatics in the morning as well as $\mathrm{NO}_{\mathrm{x}}$ emissions around noontime will be effective for mitigating the serious $\mathrm{O}_{3}$ (as well as $\mathrm{H}_{2} \mathrm{O}_{2}$ ) pollution in Tai'an city.

\section{Data Availability Statement}

Observation data are available at https://zenodo.org/record/5082201\#.YObll8gufX8. 
Acknowledgments

The authors thank Dr. Yunqiao Zhou for support in map plotting and Huan Song and Xiang Peng for helpful discussions. This work was supported by the National Natural Science Foundation of China (No. 91544211, 41727805, 41575121, 21707151), the National Research Program for Key issues in air pollution control (DQGG0103, DQGG0209, DQGG0206), and the National Key Research and Development Program of China (2016YFC0202200, 2017YFC0209703, 2017YFF0108301).

\section{References}

Anastasio, C., Faust, B. C., \& Allen, J. M. (1994). Aqueous phase photochemical formation of hydrogen peroxide in authentic cloud waters. Journal of Geophysical Research, 99(D4), 8231-8248. https://doi.org/10.1029/94jd00085

Atkinson, R., Baulch, D., Cox, R., Crowley, J., Hampson, R., Jr., Kerr, J., et al. (2001). Summary of evaluated kinetic and photochemical data for atmospheric chemistry. In: IUPAC subcommittee on gas kinetic data evaluation for atmospheric chemistry (20).

Balasubramanian, R., \& Husain, L. (1997). Observations of gas-phase hydrogen peroxide at an elevated rural site in New York. Journal of Geophysical Research, 102(D17), 21209-21220. https://doi.org/10.1029/97jd01480

Becker, K. H., Bechara, J., \& Brockmann, K. (1993). Studies on the formation of $\mathrm{H}_{2} \mathrm{O}_{2}$ in the ozonolysis of alkenes. Atmospheric Environment. Part A. General Topics, 27(1), 57-61. https://doi.org/10.1016/0960-1686(93)90070-f

Becker, K. H., Brockmann, K. J., \& Bechara, J. (1990). Production of hydrogen peroxide in forest air by reaction of ozone with terpenes. Nature, 346(6281), 256-258. https://doi.org/10.1038/346256a0

Bufalini, J. J., Gay, B. W., Jr., \& Brubaker, K. L. (1972). Hydrogen peroxide formation from formaldehyde photooxidation and its presence in urban atmospheres. Environmental Science \& Technology, 6(9), 816-821. https://doi.org/10.1021/es60068a005

Calvert, J. G., Lazrus, A., Kok, G. L., Heikes, B. G., Walega, J. G., Lind, J., \& Cantrell, C. A. (1985), Chemical mechanisms of acid generation in the troposphere, Nature, 317(6032), 27-35. https://doi.org/10.1038/317027a0

Cardelino, C. A., \& Chameides, W. L. (1995). An observation-based model for analyzing ozone precursor relationships in the urban atmosphere. Journal of the Air \& Waste Management Association, 45(3), 161-180. https://doi.org/10.1080/10473289.1995.10467356

Castell, N., Stein, A. F., Mantilla, E., Salvador, R., \& Millán, M. (2009). Evaluation of the use of photochemical indicators to assess ozone$\mathrm{NO}_{\mathrm{x}}$-VOC sensitivity in the Southwestern Iberian Peninsula. Journal of Atmospheric Chemistry, 63(1), 73-91. https://doi.org/10.1007/ s10874-010-9158-X

Claiborn, C. S., \& Aneja, V. P. (1991). Measurements of atmospheric hydrogen peroxide in the gas phase and in cloud water at Mt. Mitchell, North Carolina. Journal of Geophysical Research: Atmospheres, 96(D10), 18771-18787. https://doi.org/10.1029/91jd00931

Crowley, J. N., Pouvesle, N., Phillips, G. J., Axinte, R., Fischer, H., Petäjä, T., et al. (2018). Insights into HOx and ROx chemistry in the boreal forest via measurement of peroxyacetic acid, peroxyacetic nitric anhydride (PAN) and hydrogen peroxide. Atmospheric Chemistry and Physics. 18(18).

Cui, Y., Yin, Y., Chen, K., Zhang, X., Kuang, X., Jiang, H., et al. (2020). Characteristics and sources of WSI in North China Plain: A simultaneous measurement at the summit and foot of Mount Tai. Journal of Environmental Sciences, 92, 264-277. https://doi.org/10.1016/j. jes.2020.02.017

de Reus, M., Fischer, H., Sander, R., Gros, V., Kormann, R., Salisbury, G., et al. (2005). Observations and model calculations of trace gas scavenging in a dense Saharan dust plume during MINATROC. Atmospheric Chemistry and Physics, 5(7), 1787-1803. https://doi. org/10.5194/acp-5-1787-2005

Ding, A. J., Wang, T., Thouret, V., Cammas, J. P., \& Nedelec, P. (2008). Tropospheric ozone climatology over Beijing: Analysis of aircraft data from the MOZAIC program. Atmospheric Chemistry and Physics, 8(1), 1-13. https://doi.org/10.5194/acp-8-1-2008

Faust, B. C., Anastasio, C., Allen, J. M., \& Arakaki, T. (1993). Aqueous-phase photochemical formation of peroxides in authentic cloud and fog waters. Science, 260(5104), 73-75. https://doi.org/10.1126/science.8465202

Fischer, H., Axinte, R., Bozem, H., Crowley, J. N., Ernest, C., Gilge, S., et al. (2019). Diurnal variability, photochemical production and loss processes of hydrogen peroxide in the boundary layer over Europe. Atmospheric Chemistry and Physics, 19(18), 11953-11968. https:// doi.org/10.5194/acp-19-11953-2019

Fischer, H., Pozzer, A., Schmitt, T., Jöckel, P., Klippel, T., Taraborrelli, D., \& Lelieveld, J. (2015). Hydrogen peroxide in the marine boundary layer over the South Atlantic during the OOMPH cruise in March 2007. Atmospheric Chemistry and Physics, 15(12), 6971-6980. https:// doi.org/10.5194/acp-15-6971-2015

Gao, J., Wang, T., Ding, A. J., \& Liu, C. B. (2005). Observational study of ozone and carbon monoxide at the summit of mount Tai (1534 m a.s.l.) in central-eastern China. Atmospheric Environment, 39(26), 4779-4791. https://doi.org/10.1016/j.atmosenv.2005.04.030

Geng, G. N., Xiao, Q. Y., Zheng, Y. X., Tong, D., Zhang, Y. X., Zhang, X. Y., et al. (2019). Impact of China's air pollution prevention and control action plan on $\mathrm{PM}_{2.5}$ chemical composition over eastern China. Science China Earth Sciences, 62(12), 1872-1884. https://doi. org/10.1007/s11430-018-9353-x

Gong, Y., Xu, X., Xu, W., \& Zhang, G. (2018). Characteristics of atmospheric hydrogen peroxide at an urban site in Beijing during winter and spring. Journal of Meteorological Science, 29(4), 474-486.

Guo, J., Tilgner, A., Yeung, C., Wang, Z., Louie, P. K. K., Luk, C. W. Y., et al. (2014). Atmospheric peroxides in a polluted subtropical environment: Seasonal variation, sources and sinks, and importance of heterogeneous processes. Environmental Science \& Technology, 48(3), 1443-1450. https://doi.org/10.1021/es403229x

Hall, B. D., \& Claiborn, C. S. (1997). Measurements of the dry deposition of peroxides to a Canadian boreal forest. Journal of Geophysical Research, 102(D24), 29343-29353. https://doi.org/10.1029/97jd01113

Hammer, M. U., Vogel, B., \& Vogel, H. (2002). Findings on $\mathrm{H}_{2} \mathrm{O}_{2} / \mathrm{HNO}_{3}$ as an indicator of ozone sensitivity in Baden-Württemberg, Berlin-Brandenburg, and the Po valley based on numerical simulations. Journal of Geophysical Research, 107(D22). LOP 3-1-LOP 3-18. https://doi.org/10.1029/2000jd000211

He, S. Z., Chen, Z. M., Zhang, X., Zhao, Y., Huang, D. M., Zhao, J. N., et al. (2010). Measurement of atmospheric hydrogen peroxide and organic peroxides in Beijing before and during the 2008 Olympic Games: Chemical and physical factors influencing their concentrations Journal of Geophysical Research, 115, D1730710. https://doi.org/10.1029/2009jd013544

Heland, J., Kleffmann, J., Kurtenbach, R., \& Wiesen, P. (2001). A new instrument to measure gaseous nitrous acid (HONO) in the atmosphere. Environmental Science \& Technology, 35(15), 3207-3212. https://doi.org/10.1021/es000303t

Herrmann, H., Schaefer, T., Tilgner, A., Styler, S. A., Weller, C., Teich, M., \& Otto, T. (2015). Tropospheric aqueous-phase chemistry: Kinetics, mechanisms, and its coupling to a changing gas phase. Chemical Review, 115, 4259-4334. https://doi.org/10.1021/cr500447k

Hua, W., Chen, Z. M., Jie, C. Y., Kondo, Y., Hofzumahaus, A., Takegawa, N., et al. (2008), Atmospheric hydrogen peroxide and organic hydroperoxides during PRIDE-PRD'06, China: Their concentration, formation mechanism and contribution to secondary aerosols, Atmospheric Chemistry and Physics, 8(22), 6755-6773. https://doi.org/10.5194/acp-8-6755-2008

Kanaya, Y., Akimoto, H., Wang, Z., Pochanart, P., Kawamura, K., Liu, Y., et al. (2013). Overview of the Mount Tai experiment (MTX2006) in central East China in June 2006: Studies of significant regional air pollution. Atmospheric Chemistry and Physics. 13(16). https://doi. org/10.5194/acp-13-8265-2013

Lazrus, A. L., Kok, G. L., Lind, J. A., Gitlin, S. N., Heikes, B. G., \& Shetter, R. E. (1986), Automated fluorometric method for hydrogen-peroxide in air, Analytical Chemistry, 58(3), 594-597, https://doi.org/10.1021/Ac00294a024 
Lee, M., Heikes, B. G., Jacob, D. J., Sachse, G., \& Anderson, B. (1997). Hydrogen peroxide, organic hydroperoxide, and formaldehyde as primary pollutants from biomass burning. Journal of Geophysical Research, 102(D1), 1301-1309. https://doi.org/10.1029/96jd01709

Lee, M., Kie, J. A., Kim, Y. M., \& Lee, G. (2008). Characteristics of atmospheric hydrogen peroxide variations in Seoul megacity during 2002-2004. The Science of the Total Environment, 393(2-3), 299-308. https://doi.org/10.1016/j.scitotenv.2007.11.037

Li, J. R., Zhu, C., Chen, H., Fu, H. B., Xiao, H., Wang, X. F., et al. (2020). A more important role for the ozone-S(IV) oxidation pathway due to decreasing acidity in clouds. Journal of Geophysical Research: Atmospheres, 125(18), e2020JD033220. https://doi. org/10.1029/2020jd033220

Liang, H., Chen, Z. M., Huang, D., Zhao, Y., \& Li, Z. Y. (2013). Impacts of aerosols on the chemistry of atmospheric trace gases: A case study of peroxides and $\mathrm{HO}_{2}$ radicals. Atmospheric Chemistry and Physics, 13(22), 11259-11276. https://doi.org/10.5194/acp-13-11259-2013

Liu, C., Mu, Y., Zhang, C., Zhang, Z., Zhang, Y., Liu, J., et al. (2016). Development of gas chromatography-flame ionization detection system with a single column and liquid nitrogen-free for measuring atmospheric C2-C12 hydrocarbons. Journal of Chromatography A, 1427, 134-141. https://doi.org/10.1016/j.chroma.2015.11.060

Liu, J., Steinberg, S. M., \& Johnson, B. J. (2003). A high performance liquid chromatography method for determination of gas-phase hydrogen peroxide in ambient air using Fenton's chemistry. Chemosphere, 52(5), 815-823. https://doi.org/10.1016/s0045-6535(03)00260-1

Liu, T., Clegg, S. L., \& Abbatt, J. P. (2020). Fast oxidation of sulfur dioxide by hydrogen peroxide in deliquesced aerosol particles. Proceedings of the National Academy of Sciences of the United Stated of America, 117(3), 1354-1359. https://doi.org/10.1073/pnas.1916401117

Möller, D. (1989). The possible role of $\mathrm{H}_{2} \mathrm{O}_{2}$ in new-type forest decline. Atmospheric Environment, 23(7), 1625-1627. https://doi. org/10.1016/0004-6981(89)90430-7

Nguyen, T. B., Crounse, J. D., Teng, A. P., St Clair, J. M., Paulot, F., Wolfe, G. M., \& Wennberg, P. O. (2015). Rapid deposition of oxidized biogenic compounds to a temperate forest. Proceedings of the National Academy of Sciences of the United Stated of America, 112(5), E392-E401. https://doi.org/10.1073/pnas.1418702112

Nunnermacker, L. J., Weinstein-Lloyd, J. B., Hillery, B., Giebel, B., Kleinman, L. I., Springston, S. R., et al. (2008). Aircraft and ground-based measurements of hydroperoxides during the 2006 MILAGRO field campaign. Atmospheric Chemistry and Physics, 8(24), 7619-7636. https://doi.org/10.5194/acp-8-7619-2008

O'Sullivan, D., Heikes, B., Lee, M., Chang, W., Gregory, G., Blake, D., \& Sachse, G. (1999). Distribution of hydrogen peroxide and methylhydroperoxide over the Pacific and South Atlantic Oceans. Journal of Geophysical Research, 104(D5), 5635-5646. https://doi. org/10.1029/98jd01250

Pang, X., \& Mu, Y. (2006). Seasonal and diurnal variations of carbonyl compounds in Beijing ambient air. Atmospheric Environment, 40(33), 6313-6320. https://doi.org/10.1016/j.atmosenv.2006.05.044

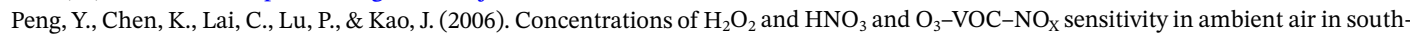
ern Taiwan. Atmospheric Environment, 40(35), 6741-6751. https://doi.org/10.1016/j.atmosenv.2006.05.079

Penkett, S. A., Jones, B. M. R., Brice, K. A., \& Eggleton, A. E. J. (1979). Importance of atmospheric ozone and hydrogen-peroxide in oxidizing sulfur-dioxide in cloud and rainwater. Atmospheric Environment, 13(1), 123-137. https://doi.org/10.1016/0004-6981(79)90251-8

Pradhan, M., Kalberer, M., Griffiths, P. T., Braban, C. F., Pope, F. D., Cox, R. A., \& Lambert, R. M. (2010). Uptake of gaseous hydrogen peroxide by submicrometer titanium dioxide aerosol as a function of relative humidity. Environmental Science \& Technology, 44(4), 1360-1365. https://doi.org/10.1021/es902916f

Qin, M., Chen, Z., Shen, H., Li, H., Wu, H., \& Wang, Y. (2018). Impacts of heterogeneous reactions to atmospheric peroxides: Observations and budget analysis study. Atmospheric Environment, 183, 144-153. https://doi.org/10.1016/j.atmosenv.2018.04.005

Reeves, C. E., \& Penkett, S. A. (2003). Measurements of peroxides and what they tell us. Chemical Reviews, 103(12), 5199-5218. https:// doi.org/10.1021/cr0205053

Ren, Y., Ding, A., Wang, T., Shen, X., Guo, J., Zhang, J., et al. (2009). Measurement of gas-phase total peroxides at the summit of Mount Tai in China. Atmospheric Environment, 43(9), 1702-1711. https://doi.org/10.1016/j.atmosenv.2008.12.020

Romanias, M. N., El Zein, A., \& Bedjanian, Y. (2012). Heterogeneous interaction of $\mathrm{H}_{2} \mathrm{O}_{2}$ with $\mathrm{TiO}_{2}$ surface under dark and UV light irradiation conditions. The Journal of Physical Chemistry A, 116(31), 8191-8200. https://doi.org/10.1021/jp305366v

Sakugawa, H., \& Kaplan, I. R. (1993). Comparison of $\mathrm{H}_{2} \mathrm{O}_{2}$ and $\mathrm{O}_{3}$ content in atmospheric samples in the San Bernardino Mountains, Southern California Atmospheric Environment. Part A. General Topics, 27(9), 1509-1515. https://doi.org/10.1016/0960-1686(93)90136-m

Sander, S., Friedl, R., Barker, J., Golden, D., Kurylo, M., Wine, P., et al. (2003). Chemical kinetics and photochemical data for use in atmospheric studies, evaluation number 14 (25, p. 334). JPL Publishing.

Shen, X., Lee, T., Guo, J., Wang, X., Li, P., Xu, P., et al. (2012). Aqueous phase sulfate production in clouds in eastern China. Atmospheric Environment, 62, 502-511. https://doi.org/10.1016/j.atmosenv.2012.07.079

Shepson, P., Bottenheim, J., Hastie, D., \& Venkatram, A. (1992). Determination of the relative ozone and PAN deposition velocities at night. Geophysical Research Letters, 19(11), 1121-1124. https://doi.org/10.1029/92gl01118

Sillman, S. (1995). The use of $\mathrm{NO}_{y}, \mathrm{H}_{2} \mathrm{O}_{2}$, and $\mathrm{HNO}_{3}$ as indicators for ozone- $\mathrm{NO}_{\mathrm{x}}$-hydrocarbon sensitivity in urban locations. Journal of Geophysical Research, 100(D7), 14175-14188. https://doi.org/10.1029/94jd02953

Sillman, S., Al-Wali, K. I., Marsik, F. J., Nowacki, P., Samson, P. J., Rodgers, M. O., et al. (1995). Photochemistry of ozone formation in Atlanta, GA-Models and measurements. Atmospheric Environment, 29(21), 3055-3066. https://doi.org/10.1016/1352-2310(95)00217-m

Sillman, S., He, D., Pippin, M. R., Daum, P. H., Imre, D. G., Kleinman, L. I., et al. (1998). Model correlations for ozone, reactive nitrogen, and peroxides for Nashville in comparison with measurements: Implications for $\mathrm{O}_{3}-\mathrm{NO}_{\mathrm{x}}$-hydrocarbon chemistry. Journal of Geophysical Research, 103(D17), 22629-22644. https://doi.org/10.1029/98jd00349

Sommariva, R., Cox, S., Martin, C., Borońska, K., Young, J., Jimack, P. K., et al. (2020). AtChem (version 1), an open-source box model for the master chemical mechanism. Geoscientific Model Development, 13(1), 169-183. https://doi.org/10.5194/gmd-13-169-2020

Sun, L., Xue, L., Wang, T., Gao, J., Ding, A., Cooper, O. R., et al. (2016). Significant increase of summertime ozone at Mount Tai in Central Eastern China. Atmospheric Chemistry and Physics, 16(16).

Tan, Z., Rohrer, F., Lu, K., Ma, X., Bohn, B., Broch, S., et al. (2018). Wintertime photochemistry in Beijing: Observations of RO ${ }_{\mathrm{x}}$ radical concentrations in the North China Plain during the BEST-ONE campaign. Atmospheric Chemistry and Physics, 18(16), 12391-12411. https://doi.org/10.5194/acp-18-12391-2018

Tang, G., Zhang, J., Zhu, X., Song, T., Münkel, C., Hu, B., et al. (2016). Mixing layer height and its implications for air pollution over Beijing, China. Atmospheric Chemistry and Physics, 16(4), 2459-2475. https://doi.org/10.5194/acp-16-2459-2016

Tanner, R. L., \& Schorran, D. E. (1995), Measurements of gaseous peroxides near the Grand-Canyon implication for summertime visibility impairment from aqueous-phase secondary sulfate formation, Atmospheric Environment, 29(10), 1113-1122, https://doi.org/10.1016/1352-2310(95)00047-3 
Tao, F., Gonzalez-Flecha, B., \& Kobzik, L. (2003). Reactive oxygen species in pulmonary inflammation by ambient particulates. Free Radical Biology and Medicine, 35(4), 327-340. https://doi.org/10.1016/s0891-5849(03)00280-6

Valverde-Canossa, J., Ganzeveld, L., Rappenglück, B., Steinbrecher, R., Klemm, O., Schuster, G., \& Moortgat, G. (2006). First measurements of $\mathrm{H}_{2} \mathrm{O}_{2}$ and organic peroxides surface fluxes by the relaxed eddy-accumulation technique. Atmospheric Environment, 40, 55-67. https://doi.org/10.1016/j.atmosenv.2006.03.038

Valverde-Canossa, J., Grossmann, D., Neeb, P., \& Moortgat, G. (2001). Ozonolysis of biogenic and anthropogenic alkenes as a relevant source of tropospheric $\mathrm{H}_{2} \mathrm{O}_{2}$ and organic hydroperoxides.

Vermeuel, M. P., Novak, G. A., Alwe, H. D., Hughes, D. D., Kaleel, R., Dickens, A. F., et al. (2019). Sensitivity of ozone production to $\mathrm{NO}_{\mathrm{X}}$ and VOC along the Lake Michigan Coastline. Journal of Geophysical Research: Atmospheres, 124(20), 10989-11006. https://doi. org/10.1029/2019jd030842

Walker, S. J., Evans, M. J., Jackson, A. V., Steinbacher, M., Zellweger, C., \& McQuaid, J. B. (2006), Processes controlling the concentration of hydroperoxides at Jungfraujoch Observatory, Switzerland, Atmospheric Chemistry and Physics, 6, 5525-5536. https://doi.org/10.5194/ acp-6-5525-2006

Wang, Y., Chen, Z., Wu, Q., Liang, H., Huang, L., Li, H., et al. (2016). Observation of atmospheric peroxides during Wangdu campaign 2014 at a rural site in the North China Plain. Atmospheric Chemistry and Physics, 16(17), 10985-11000. https://doi.org/10.5194/ acp-16-10985-2016

Watanabe, K., Ishizaka, Y., \& Tanaka, H. (1995). Measurements of atmospheric peroxides concentrations near the summit of Mt. Norikura in Japan. Journal of the Meteorological Society of Japan, 73(6), 1153-1160. https://doi.org/10.2151/jmsj1965.73.6_1153

Watanabe, K., Yachi, C., Nishibe, M., Michigami, S., Saito, Y., Eda, N., et al. (2016). Measurements of atmospheric hydroperoxides over a rural site in central Japan during summers using a helicopter. Atmospheric Environment, 146, 174-182. https://doi.org/10.1016/j. atmosenv.2016.06.074

Weinstein-Lloyd, J., Lee, J., Daum, P., Kleinman, L., Nunnermacker, L., Springston, S., \& Newman, L. (1998). Measurements of peroxides and related species during the 1995 summer intensive of the Southern Oxidants Study in Nashville, Tennessee. Journal of Geophysical Research, 103(D17), 22361-22373.

Ye, C., Liu, P., Ma, Z., Xue, C., Zhang, C., Zhang, Y., et al. (2018). High $\mathrm{H}_{2} \mathrm{O}_{2}$ concentrations observed during haze periods during the winter in Beijing: Importance of $\mathrm{H}_{2} \mathrm{O}_{2}$ oxidation in sulfate hormation. Environmental Science and Technology Letters, 5, 757-763. https://doi org/10.1021/acs.estlett.8b00579

Zhang, Q., Liu, J., He, Y., Yang, J., Gao, J., Liu, H., et al. (2018). Measurement of hydrogen peroxide and organic hydroperoxide concentrations during autumn in Beijing, China. Journal of Environmental Sciences, 64, 72-81. https://doi.org/10.1016/j.jes.2016.12.015

Zhang, Q., Yuan, B., Shao, M., Wang, X., Lu, S., Lu, K., et al. (2014). Variations of ground-level $\mathrm{O}_{3}$ and its precursors in Beijing in summertime between 2005 and 2011. Atmospheric Chemistry and Physics, 14(12), 6089-6101. https://doi.org/10.5194/acp-14-6089-2014

Zhao, Y., Chen, Z., Shen, X., \& Zhang, X. (2011). Kinetics and mechanisms of heterogeneous reaction of gaseous hydrogen peroxide on mineral oxide particles. Environmental Science \& Technology, 45(8), 3317-3324. https://doi.org/10.1021/es104107c

Zhou, L. H., Zhang, J., Zheng, X. H., Xue, W. H., \& Zhu, S. G. (2019). Impacts of chemical and synoptic processes on summer tropospheric ozone trend in North China. Advances in Meteorology, 2019, 3148432. https://doi.org/10.1155/2019/3148432

Zhu, X., Tang, G., Guo, J., Hu, B., Song, T., Wang, L., et al. (2018). Mixing layer height on the North China Plain and meteorological evidence of serious air pollution in southern Hebei. Atmospheric Chemistry and Physics, 18(7), 4897-4910. https://doi.org/10.5194/ acp-18-4897-2018

Zuo, Y., \& Hoigné, J. (1993). Evidence for photochemical formation of $\mathrm{H}_{2} \mathrm{O}_{2}$ and oxidation of $\mathrm{SO}_{2}$ in authentic fog water. Science, 260(5104), 71-73. https://doi.org/10.1126/science.260.5104.71 